\title{
Schoolkeuzemotieven van ouders en leerlingen in het primair onderwijs
}

Citation for published version (APA):

Allen, J., Bijlsma, I., Borghans, L., \& Poulissen, D. (2016). Schoolkeuzemotieven van ouders en leerlingen in het primair onderwijs. ROA. ROA Reports No. 004 https://doi.org/10.26481/umarep.2016004

Document status and date:

Published: 01/01/2016

DOI:

10.26481/umarep.2016004

Document Version:

Publisher's PDF, also known as Version of record

\section{Please check the document version of this publication:}

- A submitted manuscript is the version of the article upon submission and before peer-review. There can be important differences between the submitted version and the official published version of record.

People interested in the research are advised to contact the author for the final version of the publication, or visit the DOI to the publisher's website.

- The final author version and the galley proof are versions of the publication after peer review.

- The final published version features the final layout of the paper including the volume, issue and page numbers.

Link to publication

\footnotetext{
General rights rights.

- You may freely distribute the URL identifying the publication in the public portal. please follow below link for the End User Agreement:

www.umlib.nl/taverne-license

Take down policy

If you believe that this document breaches copyright please contact us at:

repository@maastrichtuniversity.nl

providing details and we will investigate your claim.
}

Copyright and moral rights for the publications made accessible in the public portal are retained by the authors and/or other copyright owners and it is a condition of accessing publications that users recognise and abide by the legal requirements associated with these

- Users may download and print one copy of any publication from the public portal for the purpose of private study or research.

- You may not further distribute the material or use it for any profit-making activity or commercial gain

If the publication is distributed under the terms of Article $25 \mathrm{fa}$ of the Dutch Copyright Act, indicated by the "Taverne" license above, 
Research Centre for Education and the Labour Market | ROA

\section{Schoolkeuzemotieven van ouders en leerlingen in het primair onderwijs}

\section{ROA Rapport}

ROA-R-2016/4

Researchcentrum voor Onderwijs en Arbeidsmarkt | ROA Research Centre for Education and the Labour Market / ROA 


\section{SCHOOLKEUZEMOTIEVEN VAN OUDERS EN LEERLINGEN IN HET PRIMAIR ONDERWIJS}

ROA-R-2016/4

Jim Allen*

Ineke Bijlsma*

Lex Borghans**

Davey Poulissen*

* Researchcentrum voor Onderwijs en Arbeidsmarkt

** Onderzoeksgroep Economics of Education, Universiteit Maastricht 


\section{Colofon}

(C) Researchcentrum voor Onderwijs en Arbeidsmarkt (ROA). Niets uit deze uitgave mag op enige manier worden verveelvoudigd zonder voorafgaande schriftelijke toestemming van de directeur van het ROA.

\section{Researchcentrum voor Onderwijs en Arbeidsmarkt}

School of Business and Economics

Maastricht University

email: secretary-roa-sbe@maastrichtuniversity.nl

website: www.roa.nl

ISBN: 978-90-5321-551-7

\section{Vormgeving}

ROA secretariaat, Maastricht 


\section{INHOUD}

01 Inleiding

02 Data en methoden

2.1 De vignettenanalyse 5

$\begin{array}{ll}2.2 \text { DUO-analyses } & 14\end{array}$

03 Directe vergelijkingen tussen denominaties $\quad 17$

3.1 Voorkeur en aanbod 22

$\begin{array}{lr}04 \text { Vignettenanalyses } & 27\end{array}$

$\begin{array}{ll}05 & \text { Analyse van populatiedata van leerlingen }\end{array}$

06 Conclusies $\quad 51$ 


\section{VOORWOORD}

Naar aanleiding van de uitwerking van het concept-wetsvoorstel Meer Ruimte voor Nieuwe Scholen heeft de Tweede Kamer een motie aangenomen waarin zij de staatssecretaris oproept om onderzoek te laten doen naar de motieven en behoeften van ouders en leerlingen bij het kiezen van een school. Directe aanleiding voor het wetsvoorstel was de gedachte dat het huidig systeem om een nieuwe school te mogen beginnen wellicht niet meer past bij de actuele maatschappelijke situatie. Bij het beoordelen van nieuwe schoolinitiatieven wordt nu naar levensovertuiging en aantallen leerlingen gekeken. Dit systeem dateert uit de tijd van de verzuiling, en strookt tegenwoordig wellicht niet meer met de belangstelling van ouders en leerlingen in de regio. Er is echter weinig bekend over de daadwerkelijke motieven voor deze belangstelling, en derhalve over de mate waarin de ouders en leerlingen wellicht andere keuzes zouden maken wanneer andere mogelijkheden zouden bestaan.

Het Ministerie van Onderwijs, Cultuur en Wetenschappen heeft aan de onderzoeksgroep Economics of Education en het Researchcentrum voor Onderwijs en Arbeidsmarkt van de Universiteit Maastricht verzocht om de voorkeuren van ouders met kinderen in het primair en/of het voortgezet onderwijs, evenals van de kinderen zelf, in kaart te brengen. De overkoepelende onderzoeksvraag luidt: Wat zijn de belangrijkste motieven en behoeften van ouders en leerlingen bij het kiezen van een nieuwe dan wel bestaande school in het primair onderwijs (po)? In een ander rapport wordt ingegaan op deze vraag voor het voortgezet onderwijs. 


\section{MANAGEMENTSAMENVATTING}

\section{Hoofdvragen}

De overkoepelende onderzoeksvragen in dit rapport luiden: Wat zijn de belangrijkste motieven en behoeften van ouders en leerlingen bij het kiezen van een nieuwe dan wel bestaande school in het primair onderwijs? Hoe groot is de diversiteit in deze voorkeuren en in hoeverre voorziet het bestaande aanbod in deze behoefte? Om deze vragen te onderzoeken hebben we drie uitgebreide deelanalyses verricht:

- een analyse van de afstanden die ouders bereid zijn om hun kind extra te laten reizen voor hun meest geprefereerde denominatie;

- een vignettenanalyse om voorkeuren van ouders en leerlingen over een breder scala aan attributen bloot te leggen;

- een analyse van populatiedata om feitelijke schoolkeuzes van ouders en leerlingen te analyseren.

In dit rapport wordt bij alle analyses afstand als gemeenschappelijke meetlat gehanteerd. Hierdoor kunnen voorkeuren voor verschillende schoolattributen (denominaties, pedagogische-didactische aanpakken, schoolkwaliteit en andere bijzondere kenmerken) direct met elkaar worden vergeleken.

\section{Motieven van ouders en leerlingen bij schoolkeuze}

Vrijwel alle ouders hebben een voorkeur voor een bepaalde denominatie, pedagogischdidactische visie of bijzonder kenmerk en zijn bereid hiervoor (hun kind) verder te (laten) reizen. Denominatie is een belangrijk motief voor ouders bij de schoolkeuze, maar bijzondere kenmerken en pedagogische aanpak zijn in vergelijkbare mate ook belangrijk. Voor alle drie van de genoemde schoolattributen zijn er veel ouders die bereid zijn om hun kinderen desnoods een substantieel extra afstand te laten reizen om hun meest geprefereerde uitkomst te realiseren. Dit geldt ook voor de kinderen zelf.

\section{Diversiteit in voorkeuren van ouders en leerlingen}

Het is niet zo dat alle ouders en kinderen even sterke voorkeuren hebben voor denominatie, pedagogische aanpak en bijzondere kenmerken. 10\% van de ouders is helemaal niet bereid hun kinderen verder te laten reizen om hun meest geprefereerde denominatie te realiseren. Anderzijds is er een kleine groep ouders die bereid zijn om hun kinderen desnoods tientallen kilometers verder te laten reizen. Ook de sterkte van voorkeuren voor pedagogische aanpak en bijzondere kenmerken varieert aanzienlijk tussen 
deelpopulaties. Deze verschillen hangen samen met onder andere denominatie, regio, mate van geloof en opleidingsniveau van de ouders.

\section{Toereikendheid bestaand aanbod}

Uit het rapport komt naar voren dat vrijwel iedereen kosten maakt om naar school te gaan. Deze kosten bestaan uit de feitelijk gereisde afstand, plus een eventueel verlies wanneer de meest geprefereerde school niet binnen bereik blijkt te zijn. Voor de meeste mensen blijken de kosten niet bijzonder hoog te zijn. Voor ongeveer 1\% van de populatie lopen deze kosten echter behoorlijk op, zoals blijkt uit afstanden die tot boven de 10 kilometer oplopen. De kosten bestaan met name uit de feitelijk gereisde afstand, maar ook voor een deel uit verlies door het niet naar een school van de meest geprefereerde denominatie te kunnen gaan.

Uit de analyse van de leerlingenregisterdata blijken grote regionale verschillen in het kwantitatieve aanbod van scholen, en ook in de plaatsing van deze scholen in relatie tot de woonlocatie van leerlingen. Dit vertaalt zich in grote verschillen in de afstand die men minimaal moeten afleggen om naar een school te kunnen gaan. De meeste kinderen gaan óf naar de dichtstbijzijnde school, óf naar een andere school waarvoor ze maximaal 1 kilometer verder moeten reizen. Ongeveer $1 \%$ van de populatie reist echter enkele tientallen kilometers bovenop de afstand naar de dichtstbijzijnde scholen. Door deze groep van ongeveer 10,000 leerlingen worden dus forse kosten gemaakt.

Uit de vignettenanalyse kon zowel voor de populatie als geheel als voor individuele ouders de kenmerken van de "optimale school" worden vastgesteld. Dit is de school met de combinatie van denominatie, aanpak en bijzonder kenmerk die door respectievelijk de populatie als geheel als door individuele ouders het meest wordt gewaardeerd. Door de publieke en private optima met elkaar te vergelijken, kon worden opgemaakt dat vrijwel geen schoolkiezers helemaal tevreden te stellen zouden zijn met slechts één school in de buurt. Door het aanbod uit te breiden met scholen met een gevarieerde mix van attributen, kan de tevredenheid met het aanbod snel worden verhoogd, tot een punt waar een meerderheid van de mensen weinig behoefte zouden voelen om ver te reizen voor een betere optie. Wel blijft zelfs bij een aanbod van 20 of meer scholen met gevarieerde attributen een deel van de populatie over, dat tamelijk sterk ontevreden zou zijn met het aanbod. 


\section{1 \\ INLEIDING}

Nederland kent al bijna een eeuw een systeem van vrijheid van onderwijs, waarbij naast openbare scholen, bijzondere scholen bestaan, die voortkomen uit bepaalde maatschappelijke stromingen. Deze bijzondere scholen worden door de overheid op dezelfde wijze bekostigd als de openbare scholen. Uitgangspunt bij het stichten van een bijzondere school zijn de denominaties.' De grootste denominaties zijn ProtestantsChristelijk en Rooms-Katholiek, maar daarnaast zijn een aantal kleinere levensovertuigingen vertegenwoordigd in het schoolaanbod. Binnen deze openbare en bijzondere scholen ontstaat meer variatie voor wat betreft de pedagogisch-didactische visie van de school en andere kenmerken waarmee scholen zich profileren. Hoewel scholen de vrijheid hebben hun eigen invulling aan het onderwijs te geven, zijn de denominaties momenteel de enige grond om in aanmerking te komen voor bekostiging van een school. De vraag is in hoeverre deze invalshoek vanuit levensovertuigingen bij de stichting van scholen nog past bij de belangstelling van ouders en leerlingen in de regio.

Voorkeuren van ouders voor scholen met bepaalde kenmerken of identiteit lopen uiteen. In de praktijk zal nooit het volledige scala aan mogelijkheden in de nabijheid beschikbaar zijn. Dat betekent dat de afstand tot een school die de voorkeur van ouders heeft erg groot kan zijn of dat een school in de buurt die een kenmerk heeft dat de ouders aanspreekt, andere kenmerken kan hebben die juist minder passen bij hun kijk op goed onderwijs. In de praktijk moeten er dus afwegingen worden gemaakt, en is de vraag in hoeverre het bestaande aanbod voorziet in de behoeften die er onder ouders leven.

De overkoepelende onderzoeksvraag in dit onderzoek luidt: Wat zijn de belangrijkste motieven en behoeften van ouders en leerlingen bij het kiezen van een nieuwe dan wel bestaande school in het primair onderwijs? Hoe groot is de diversiteit in deze voorkeuren en in hoeverre voorziet het bestaande aanbod in deze behoefte? Een voorkeur voor een bepaald soort school is niet absoluut, maar betekent altijd een afweging met andere kenmerken van de deze school. In dit rapport gebruiken we afstand als een schaal voor voorkeuren. Hoe sterker de voorkeur, hoe verder mensen bereid zijn om te

1 Om onnodig omslachtige formuleringen te voorkomen wordt in dit rapport de term "denominatie" soms ook gebruikt als een algemene term voor de verschillende denominaties binnen het bijzonder onderwijs én het openbare onderwijs. 
reizen om deze wens vervuld te krijgen. Door zo'n maat te gebruiken kan de diversiteit van het aanbod worden gekwantificeerd.

We analyseren de voorkeuren van ouders en leerlingen in het basisonderwijs door hen zowel hypothetische keuzes voor te leggen als door naar de feitelijke schoolkeuzes te kijken. Voor de feitelijke schoolkeuze werken we met het schoolattribuut denominatie, omdat dit het enige attribuut is dat we op dit moment van alle scholen kennen. De hypothetische keuzes maken het mogelijk om de voorkeuren van ouders te onderzoeken, zonder dat deze ingeperkt worden door het feitelijk aanbod in de omgeving.

\section{Leeswijzer}

Het rapport is als volgt opgebouwd. Na een beschrijving van de gebruikte data en methodologie in paragraaf 2 worden in paragraaf 3 de voorkeuren in eerst instantie geanalyseerd in termen van de traditionele denominaties. Hoe ver zijn mensen bereid om te reizen om een school te krijgen van de denominatie die hen aanspreekt? Door deze gegevens te relateren aan de feitelijke spreiding van scholen in Nederland kan de diversiteit van het aanbod qua denominaties worden gekwantificeerd. Er wordt hierbij nagegaan of specifieke voorkeuren het lastig maken voor ouders om hun kind op de school van hun voorkeur te krijgen. Vervolgens wordt bepaald in hoeverre de diversiteit in het scholenaanbod (of gebrek daaraan) in de eigen regio tot hogere "kosten" leiden voor ouders en kinderen. Deze kosten worden uitgedrukt in de extra afstand die men moet afleggen en/of het niet kunnen realiseren van de eigen voorkeuren.

Vervolgens wordt in paragraaf 4 de beschrijving van de hypothetische scholen uitgebreid, door andere kenmerken toe te voegen. Zo kunnen we zien welke kenmerken door ouders worden gewaardeerd en hoe divers deze voorkeuren zijn, maar ook hoeveel de waardering voor scholen nog kan toenemen op basis van deze andere kenmerken. Het zou aan de ene kant zo kunnen zijn dat de in hoofdstuk 2 en 3 onderzochte diversiteit qua denominaties ouders al de variatie biedt waar ze behoefte aan hebben, maar aan de andere kant zou het zo kunnen zijn dat variatie in andere kenmerken de tevredenheid met het aanbod aanzienlijk zou doen toenemen. We kijken niet alleen hoe ouders, maar ook hoe leerlingen in groep 7 en 8 deze kenmerken waarderen. In een laatste stap voegen we gegevens over de schoolcompositie toe aan de analyse, om te kijken in hoeverre voorkeuren over de herkomst van de medeleerlingen de voorkeuren over schoolkenmerken veranderen.

Om een beeld te geven van verschillen in voorkeuren in de populatie, worden de voorkeuren ook apart bekeken per regio, mate van geloof, en opleidingsniveau van de kostwinner.

Tenslotte gaan we in paragraaf 5 in op de feitelijk schoolkeuzes. Door deze keuzes te relateren aan alternatieve mogelijkheden binnen dezelfde buurt, kan worden nagegaan in hoeverre de betrokkenen blijk geven van een sterke voorkeur te hebben voor scholen met een bepaald eigen profiel of karakter. Als de ouders/leerlingen geen duide- 
lijke voorkeur voor bepaalde scholen hebben zal de schoolkeuze in hoge mate bepaald worden door de afstand tot een school. Bij deze statistische analyse kunnen impliciete schoolvoorkeuren worden vastgesteld zonder dat daarbij gebruikt wordt gemaakt van kenmerken van een school. 



\section{2 \\ DATA EN METHODEN}

Voor dit onderzoek zijn twee databronnen gebruikt. Ten eerste wordt door middel van een vignettenonderzoek een analyse verricht naar de voorkeuren van ouders en leerlingen voor verschillende attributen van scholen die een rol zouden kunnen spelen bij hun schoolkeuze. Ten tweede wordt door middel van een analyse van gedetailleerde gegevens over scholen en leerlingen in de door DUO beheerde registratiebestanden de werkelijke diversiteit in het aanbod van scholen in kaart gebracht.

\subsection{De vignettenanalyse}

\section{Data en indicatoren}

Vignettenanalyse wordt vaak gebruikt door marktonderzoekers om preferenties van respondenten voor specifieke attributen van producten vast te stellen. Het kan inzicht geven in hoeverre de vraag naar een bepaald product of dienst gerelateerd is aan specifieke attributen daarvan. In een onderzoek over auto's, zou men bijvoorbeeld willen weten in hoeverre de vraag ernaar wordt beïnvloed door de maximale snelheid, het brandstofverbruik, de kleur, de ruimte voor passagiers en bagage, enzovoorts. In plaats van rechtstreeks te vragen waarom respondenten een bepaald product prefereren, of welke kenmerken van het product zij het belangrijkst vinden, maken vignettenstudies gebruik van een meer realistisch kader. Door respondenten voldoende verschillende profielen te laten evalueren of daaruit een keuze te laten maken, geven resultaten van vignettenstudies een maat voor de waarde van bepaalde attributen van het product in relatie tot andere attributen.

Een voordeel van vignettenanalyse boven meer conventionele vormen van onderzoek is dat het respondenten dwingt om hun keuzes en preferenties expliciet te maken. In een reguliere enquête zouden ouders en leerlingen alle denkbare attributen van scholen de denominatie, didactiek, kwaliteit, sfeer, afstand vanaf het ouderlijk huis - een zwaar gewicht kunnen toekennen. Aan deze informatie hebben we echter niet zo veel. In de praktijk moeten ouders en leerlingen meestal kiezen, omdat scholen die ze in alle opzichten als 'excellent' beschouwen praktisch onvindbaar zijn. Meestal zal daarom sprake zijn van een afweging, waarbij de ouder of leerling aanvaardt dat de gekozen school iets minder goed scoort op een aantal van de attributen. De attributen waarop ze het minst concessies willen doen zijn de attributen die er echt toedoen. 


\section{Dataverzameling}

Voor het onderzoek is uit het TNS NIPObase en het doorlopend Onderwijspanel van TNS NIPO een aselecte steekproef getrokken van zowel ouders als leerlingen uit de doelgroep. Binnen TNS NIPObase wordt een panel beheerd met zowel medewerkers in als deelnemers aan het onderwijs, van basisschool tot masterstudenten en deelnemers aan avond- en afstandsonderwijs via particuliere instellingen. Een steekproef is getrokken van voldoende omvang om een bestand op te leveren van 750 ouders en 300 leerlingen in groep 7 en 8. Omdat TNS NIPO respondenten voor hun deelname belonen, is de dataverzameling na het bereiken van deze streefaantallen gestopt.'

De vragenlijsten zijn gebaseerd op de beschikbare literatuur over schoolkeuze en gesprekken met vertegenwoordigers uit het onderwijsveld. De respondenten kregen een aantal malen een keuze voorgelegd tussen een aantal hypothetische scholen met kenmerken die op grond van de voorstudie het meest relevant leken te zijn. Deze ouders en leerlingen zijn gevraagd om hun voorkeur aan te geven tussen basisscholen met steeds verschillende combinaties van deze kenmerken. Door herhaalde toepassing van deze zogenaamde vignettenmethode kon worden bepaald wat het relatieve belang is van de diverse kenmerken bij het maken van de keuze tussen scholen. Naast de vignetten zijn een beperkt aantal aanvullende vragen gesteld aan de ouders, en in veel mindere mate aan de leerlingen. Verder is door NIPO een databestand opgeleverd waarin ook achtergrondvariabelen uit het panelbestand zijn opgenomen (o.a. leeftijd, geslacht, regio). Deze gegevens worden gebruikt in dit onderzoek om de diversiteit in de voorkeuren van ouders te analyseren.

Uitgangspunt bij de analyse van de data is dat iedere ouder zijn eigen mate van voorkeur voor de verschillende kenmerken van een school heeft. Op basis van een zogenaamd "random coefficient" model worden deze individuele parameters geschat. Deze keuzes van de respondenten bij de vignetvragen zijn omgezet in numerieke scores die de relatieve voorkeuren van ouders en leerlingen voor verschillende schoolkenmerken weergeven. Door de scores voor alle overige attributen te relateren aan de scores voor de attribuut afstand huis-school, is het mogelijk om al deze voorkeuren uit te drukken in termen van afstand als gemeenschappelijke meetlat. Hierdoor wordt een beeld geschetst van hoeveel men voor een bepaald attribuut over heeft, en kan het relatief belang van de verschillende attributen worden bepaald.

We gaan hierbij uit van de meest geprefereerde uitkomst voor iedere respondent, en drukken de voorkeur uit in termen van de afstand die men bereid is om extra te reizen om deze uitkomst te realiseren in plaats van een bepaald alternatieve uitkomst. Hiervoor zijn verschillende referentiekaders mogelijk, zoals figuur 2.1 duidelijk maak. Deze figuur toont de cumulatieve verdelingen van de afstanden die ouders bereid zijn om hun kind te laten reizen voor de meest geprefereerde denominatie ten opzichte van alle andere denominaties.

1 Dit betreft volledig ingevulde vragenlijsten. Omdat sommige respondenten de vragenlijst slechts gedeeltelijk hebben ingevuld beschikken we bij sommige analyses over een iets groter aantal respondenten. 
FIGUUR 2.1 Cumulatieve verdeling van afstanden voor meest geprefereerde denominatie ten opzichte van alle alternatieve denominaties, ouders

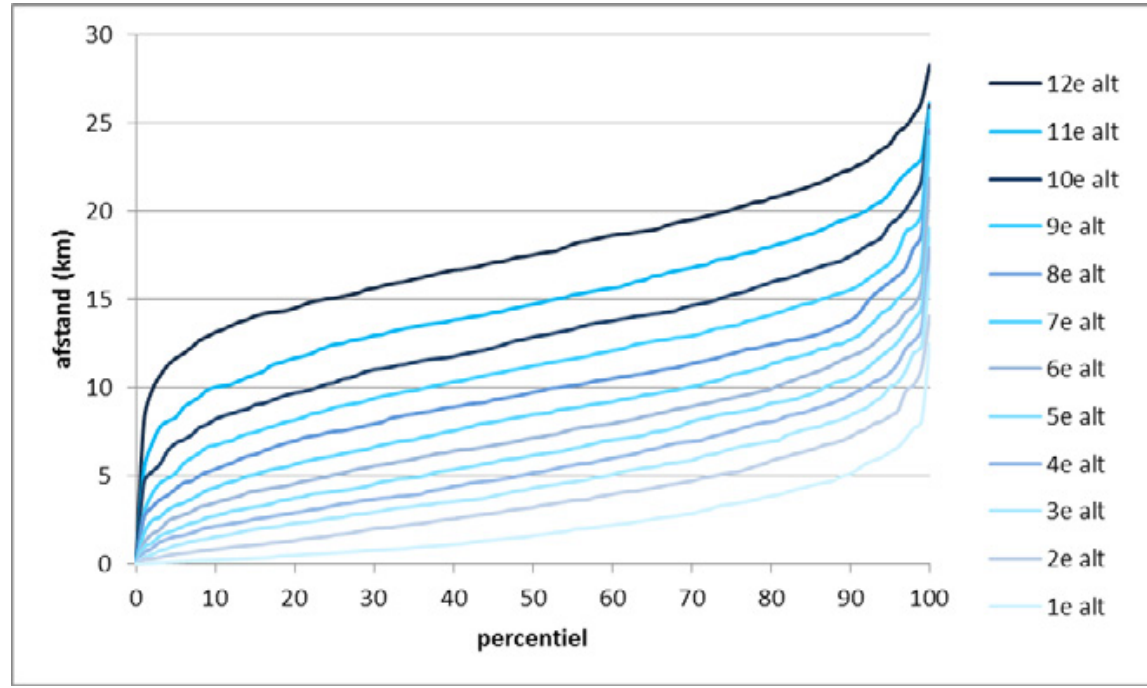

De lijnen in figuur 2.1 geven de afstanden aan die men voor de meest geprefereerde denominatie zou willen reizen, ten opzichte van de andere denominaties die in de vignetten zijn getoond. De lijnen zijn van onder naar boven geordend, van op-een-na meest geprefereerde naar minst geprefereerde denominatie. Per definitie lopen deze afstanden op, tot een punt waar vrijwel alle respondenten bereid zou zijn (hun kind) tenminste enkele kilometers te (laten) reizen om te voorkomen dat ze naar zo'n school zouden hoeven te gaan. Het gaat hier duidelijk om afkeer van bepaalde opties.

Dit is iets anders dan een uitgesproken positieve voorkeur voor scholen met een profiel dat sterk aan de wensen van schoolkiezers appelleert. De vergelijking met de op-eenna meest geprefereerde denominatie doet het meest recht aan dit begrip van schoolvoorkeur. Een dergelijke uitgesproken voorkeur zou zich immers moeten manifesteren in een bereidheid om verder te reizen ten opzichte van elke alternatieve school. Dat men vervolgens een preferentieordening aanbrengt bij de alternatieve scholen zegt ook iets over voorkeuren in algemene zin, maar zegt wellicht meer over de mate waarin men scholen van bepaalde denominaties zou willen vermijden, dan over voorkeuren in positieve zin.

Tabel 2.1 toont de attributen en bijbehorende waarden zoals ze in het onderzoek zijn gehanteerd. Zoals hieruit blijkt, zijn de attributen zeer divers. Drie attributen kunnen worden beschouwd als kenmerken waarop scholen zich tamelijk direct kunnen profileren: de denominatie, die formeel geregistreerd is voor iedere school; de bijzondere pedagogisch-didactische aanpak of visie, die ook tamelijk sterk geïnstitutionaliseerd is, maar waarvoor lang niet alle scholen kiezen; en het "bijzondere kenmerk" van de school, bestaand uit korte omschrijvingen van kenmerken waarop scholen zich zouden kunnen profileren, maar die geen formele status of erkenning genieten. 
Verder wordt in de vignetten gevarieerd op een aantal attributen waarvan aangenomen wordt dat ze voor veel ouders en kinderen belangrijk zijn: de reputatie van de school, geïndiceerd door "rapportcijfers" op onderwijskwaliteit, sfeer en veiligheid, aandacht voor individuele leerlingen, en de mate van betrokkenheid van de ouders; de klassengrootte; het aandeel hoogopgeleid ouders; het percentage niet-Nederlandse leerlingen en de afstand van huis naar school. Door rekening te houden met deze andere kenmerken worden de voorkeuren voor de drie profileringsattributen zuiverder gemeten.

Uit de tabel blijkt dat de afbeelding van de denominaties en de pedagogische-didactische aanpak op de vignetten deels afhangt van antwoorden op de achtergrondvragenlijst. Hierbij wordt een weging gehanteerd, om ervoor te zorgen dat er zowel een voldoende variëteit is, als en goede vertegenwoordiging van de "eigen" denominatie en eventueel aanpak.

TABEL 2.1 Attributen en bijbehorende waarden zoals in de vignetten zijn gebruikt

\begin{tabular}{|c|c|}
\hline Denominatie & $\begin{array}{l}\text { Openbaar, Rooms-Katholiek en Protestants-Christelijk en de overige denominaties hebben elk } \\
25 \% \text { kans om te worden gekozen. Mensen waarvan hun kind momenteel op een school van een } \\
\text { kleinere denominatie zit, of die in de vragenlijst hebben aangegeven belangstelling voor een } \\
\text { kleinere denominatie te hebben, krijgen in de helft van de gevallen deze kleine denominatie te } \\
\text { zien. Voor mensen waarvan het kind op een school van een kleine denominatie zit, en die ook } \\
\text { nog aangaven belangstelling te hebben voor een andere kleine denominatie, hebben beide } \\
\text { genoemde kleine denominaties eenderde kans genoemd te worden. De overige denominaties } \\
\text { hebben elk een gelijke kans. }\end{array}$ \\
\hline $\begin{array}{l}\text { Bijzondere pedagogisch- } \\
\text { didactische aanpak }\end{array}$ & $\begin{array}{l}\text { Deze aanpakken worden alleen opgenomen bij Openbare, Rooms-Katholieke, en PC-scholen. } \\
\text { Montessori, Dalton en Jenaplan hebben hierbij een hogere kans om te worden opgenomen } \\
\text { dan de overige pedagogisch-didactische aanpakken. In } 75 \% \text { van deze gevallen wordt } \\
\text { geen pedagogisch-didactische aanpak opgenomen (aangegeven met "-"). Bij de overige } \\
\text { denominaties staat altijd een"-". }\end{array}$ \\
\hline Bijzonder kenmerk & $\begin{array}{l}\text { * Random uit: "Creatief", "Gepersonaliseerd leren", "Kunstzinnig,", "Leren door spelen", "Muzikaal } \\
\text { onderwijs", "Onderzoekend leren", "Prestatiegericht", "Samenwerken", "Sociaal-emotionele } \\
\text { vorming", "Sportief", "Zelfstandigheid bevorderen", "Leren met ICT" }\end{array}$ \\
\hline \multicolumn{2}{|l|}{$\begin{array}{l}\text { "Rapportcijfer" uit landelijk } \\
\text { ouderonderzoek: }\end{array}$} \\
\hline Onderwijskwaliteit & Random uit $5,5.5,6,6.5,7,7.5,8$ \\
\hline Sfeer en veiligheid & Random uit $5,5.5,6,6.5,7,7.5,8$ \\
\hline $\begin{array}{l}\text { Aandacht voor individuele } \\
\text { leerlingen }\end{array}$ & Random uit $5,5.5,6,6.5,7,7.5,8$ \\
\hline Betrokkenheid ouders & Random uit $5,5.5,6,6.5,7,7.5,8$ \\
\hline Klassengrootte & Random getal tussen 18 en 30 \\
\hline $\begin{array}{l}\text { Percentage niet-Nederlandse } \\
\text { leerlingen (alleen ouders) }\end{array}$ & Random uit $0 \%, 10 \%, 20 \%, 30 \%, 40 \%, 50 \%, 60 \%, 70 \%$ \\
\hline $\begin{array}{l}\text { Percentage leerlingen van } \\
\text { hoog-opgeleide ouders (alleen } \\
\text { ouders) }\end{array}$ & Random uit $0 \%, 10 \%, 20 \%, 30 \%, 40 \%, 50 \%, 60 \%, 70 \%$ \\
\hline
\end{tabular}



meter, 1000 meter: elk $7.5 \%$ kans

1200 meter, 1400 meter, 1600 meter, 1800 meter, 2000 meter, 2200 meter, 2400 meter, 2600 meter, 2800 meter, 3000 meter: elk $2.5 \%$ kans

Figuur 2.2 bevat een voorbeeld van een vignet zoals aan de respondent is voorgelegd. Het betreft een voorbeeld uit de vragenlijst voor po ouders. In dit voorbeeld staan de rapportcijfers bovenaan en de denominatie, visie en bijzondere kenmerken daaronder. De volgorde is op basis van het toeval gevarieerd. Uit de analyses bleek dat deze volgorde geen effect had op de keuzes die mensen maakten.

FIGUUR 2.2 Voorbeeldvignet uit po ouders vragenlijst.

\begin{tabular}{|c|c|c|c|c|}
\hline \multicolumn{5}{|c|}{$\begin{array}{l}\text { U krljgt hleronder vier scholen voorgelegd. Rangschlk de vier optles naar uw } \\
\text { voorkeur, van 1e keus tot en met } 4 \text { e keus. Kies bij de meest aantrekkelijke optie } \\
\text { voor ' } 1 \text { ' en bij de minst aantrekkelijke optie voor ' } 4 \text { '. Als u twee opties even } \\
\text { aantrekkelijk vindt, kunt ze willekeurig twee opeenvolgende rankings geven. } \\
\text { In totaal leggen we u acht van dit soort afwegingen voor. }\end{array}$} \\
\hline Kenmerk & School 1 & School 2 & School 3 & School 4 \\
\hline \multicolumn{5}{|l|}{$\begin{array}{l}\text { Rapportajfer uit } \\
\text { landelink } \\
\text { ouderonderzock: }\end{array}$} \\
\hline Onderwijekwaliteit & 6.0 & 7.0 & 7.5 & 5.5 \\
\hline Sfeer en veiligheid & 5.0 & 6.0 & 5.5 & 6.0 \\
\hline $\begin{array}{c}\text { Aandacht voor } \\
\text { individuele leerlingen }\end{array}$ & 6.5 & 5.5 & 5.5 & 8.0 \\
\hline Betrokkenheid ouders & 6.5 & 6.0 & 6.5 & 7.0 \\
\hline Richting & $\begin{array}{c}\text { Evangelische } \\
\text { Broedergemeenschap }\end{array}$ & Openbaar & Protestants-Christelijk & Openbaar \\
\hline Speciale didactiek & - & - & - & Steve Jobsschool \\
\hline Bijzonder kenmerk & $\begin{array}{l}\begin{array}{l}\text { Sociaal-emotionele } \\
\text { vorming }\end{array} \\
\end{array}$ & Sportief & Muzikaal onderwijs & Leren door spelen \\
\hline Klosscnarootte & 22 & 19 & 30 & 18 \\
\hline \multirow[t]{2}{*}{$\begin{array}{l}\text { Afstand van uw huis tot } \\
\text { school }\end{array}$} & 1200 meter & 900 meter & 1400 meter & 2000 meter \\
\hline & $\begin{array}{lll}\text { kies } & \\
\end{array}$ & $\begin{array}{lll}\text { kies } & \\
\end{array}$ & kies 1 & kies \\
\hline & & Verder & & \\
\hline
\end{tabular}

Zoals al is vermeld bevatten de vragenlijsten een aantal achtergrondvragen. Bij de leerlingenvragenlijst is dit beperkt tot de naam, locatie, denominatie en eventuele pedagogische-didactische visie. Aan de ouders is additioneel gevraagd of er een andere denominatie en/of visie bestaat die ze naast de feitelijk gekozen denominatie en even- 
tuele visie ook interessant vinden, hun eventueel geloof en de mate waarin dat voor hen belangrijk is, een aantal algemene stellingen over hun attitudes, waarden en normen.

Om de relatieve bijdrage van verschillende aspecten van de schoolkeuze goed te kunnen bepalen is aan de ouders eerst gevraagd welke school zij zouden kiezen als deze school alleen wordt getypeerd met zijn denominatie. Het kan immers zijn dat in de ogen van de respondenten de denominatie en de andere kenmerken niet los van elkaar staan. De denominatie van een school zou voor ouders een "keurmerk" kunnen zijn voor de kwaliteit, visie en aanpak van de school. Door de ouders denominaties direct met elkaar te laten vergelijken, zonder tussenkomst van de overige attributen zoals in de vignetten zijn opgenomen, kan worden vastgesteld wat de omvang van deze voorkeur is puur op basis van denominatie. Dit gebeurt door de feitelijk gekozen denominatie te laten vergelijken met achtereenvolgens Openbaar onderwijs en de twee grootste bijzondere denominaties (Protestants-Christelijk en Rooms-Katholiek). Indien de feitelijk gekozen denominatie zelf één van deze drie was, werd bij de derde vergelijking een willekeurig gekozen andere denominatie voorgelegd.

In alle drie gevallen werd gevraagd of, indien men nu voor de keuze zou staan, ze opnieuw voor de feitelijk gekozen denominatie zou kiezen, voor de andere denominatie, of geen voorkeur zouden hebben. Indien een voorkeur werd uitgesproken, werd in een vervolgvraag gevraagd hoe ver men bereid zou zijn hun kind verder te laten reizen om naar een school van de geprefereerde denominatie te laten gaan, in plaats van naar het minder geprefereerde alternatief. Achteraf is bij ieder genoemd denominatiepaar een voorkeursindicator opgebouwd gebaseerd op de extra afstand die men voor een school van een bepaalde denominatie over heeft. Hierbij zijn gevallen met geen uitgesproken voorkeur een afstand van nul toegekend.

\section{Beschrijving deelnemers}

Tabel 2.1 geeft een korte beschrijving van de deelnemers en hun huishoudens. Waar mogelijk wordt in de rechterkolom het corresponderende cijfer voor de populatie als geheel weergegeven. Zodoende kunnen we een beeld krijgen van de mate waarin onze steekproef representatief is voor het landelijk beeld. Strikte representativiteit is overigens geen voorwaarde voor de validiteit van de resultaten. Wel is wenselijk dat belangrijke deelpopulaties voldoende vertegenwoordigd zijn.

TABEL 2.2 Beschrijving van de deelnemers

\begin{tabular}{|l|r|r|r|}
\hline $\begin{array}{l}\text { Geslacht } \\
\text { \% meisje/vrouw }\end{array}$ & po ouders & poleerlingen & Landelijk (DU0) \\
\hline & $55,9 \%$ & $51,4 \%$ & $48,2 \%$ \\
\hline Leeftijd & & & \\
\hline Gemiddeld & 41,3 & 11,3 & - \\
\hline Minimum & 26 & 10 & - \\
\hline Maximum & 73 & 13 & - \\
\hline
\end{tabular}




\begin{tabular}{|c|c|c|c|}
\hline & po ouders & po leerlingen & Landelijk (DU0) \\
\hline Standaardafwijking & 6,1 & 0,8 & - \\
\hline \multicolumn{4}{|l|}{$\begin{array}{l}\text { Hoogst voltooide opleiding } \\
\text { hoofdkostwinner }\end{array}$} \\
\hline Laag & $17,2 \%$ & $18,6 \%$ & - \\
\hline Middelbaar & $37,9 \%$ & $46,7 \%$ & - \\
\hline Hoog & $44,8 \%$ & $34,7 \%$ & - \\
\hline \multicolumn{4}{|l|}{$\begin{array}{l}\text { Hoogst voltooide opleiding } \\
\text { partner kostwinner }\end{array}$} \\
\hline Laag & $15,1 \%$ & $14,2 \%$ & - \\
\hline Middelbaar & $46,3 \%$ & $55,8 \%$ & - \\
\hline Hoog & $38,6 \%$ & $30,0 \%$ & - \\
\hline \multicolumn{4}{|l|}{$\begin{array}{l}\text { Geboorteland } \\
\text { hoofdkostwinner }\end{array}$} \\
\hline Nederland & $97,1 \%$ & $94,2 \%$ & $81,1 \%$ \\
\hline buitenland - westers & $1,1 \%$ & $2,1 \%$ & $5,1 \%$ \\
\hline buitenland-niet-westers & $1,8 \%$ & $3,8 \%$ & $13,8 \%$ \\
\hline \multicolumn{4}{|l|}{$\begin{array}{l}\text { Geboorteland partner van } \\
\text { hoofdkostwinner }\end{array}$} \\
\hline Nederland & $95,1 \%$ & $95,4 \%$ & $81,9 \%$ \\
\hline buitenland - westers & $1,8 \%$ & $2,7 \%$ & $4,0 \%$ \\
\hline buitenland-niet-westers & $3,1 \%$ & $1,9 \%$ & $14,0 \%$ \\
\hline \multicolumn{4}{|l|}{ Provincie } \\
\hline Groningen & $6,4 \%$ & $2,9 \%$ & $3,1 \%$ \\
\hline Friesland (Fryslân) & $4,4 \%$ & $4,2 \%$ & $3,9 \%$ \\
\hline Drenthe & $7,2 \%$ & $6,1 \%$ & $2,9 \%$ \\
\hline Overijssel & $7,9 \%$ & $8,3 \%$ & $7,3 \%$ \\
\hline Flevoland & $3,8 \%$ & $2,6 \%$ & $2,9 \%$ \\
\hline Gelderland & $13,5 \%$ & $9,6 \%$ & $12,2 \%$ \\
\hline Utrecht & $4,8 \%$ & $8,0 \%$ & $8,2 \%$ \\
\hline Noord-Holland & $10,9 \%$ & $10,6 \%$ & $16,0 \%$ \\
\hline Zuid-Holland & $18,0 \%$ & $18,6 \%$ & $21,6 \%$ \\
\hline Zeeland & $3,1 \%$ & $4,8 \%$ & $2,1 \%$ \\
\hline Noord-Brabant & $15,0 \%$ & $17,9 \%$ & $14,4 \%$ \\
\hline Limburg & $4,8 \%$ & $6,4 \%$ & $5,4 \%$ \\
\hline N & 832 & 312 & - \\
\hline
\end{tabular}

Bij de kinderen zijn jongens en meisje ongeveer even vaak vertegenwoordigd, net als in de populatie als geheel. Bij de ouders zijn vrouwen licht in de meerderheid. De kinderen zijn allen in de leeftijd 10-13 jaar, terwijl de leeftijd van de ouders sterk varieert. In vergelij- 
king met de ouders komen de respondenten van de leerlingenvragenlijsten iets minder vaak uit gezinnen met hoogopgeleide ouders, en vaker uit kinderen waarvan de ouders middelbaar opgeleid zijn. Verreweg de meeste respondenten komen uit huishoudens met een Nederlandse hoofdkostwinner en partner. Dit wijkt af van het landelijk beeld. Hieruit kan worden geconcludeerd dat allochtonen ondervertegenwoordigd zijn in de data. Dit zou tot een vertekening kunnen leiden in de waardering voor scholendenominaties die op een niet-Christelijke levensbeschouwing zijn gebaseerd (ervan uitgaande dat allochtone leerlingen relatief vaak op zulke scholen zitten), maar er is geen reden om te verwachten dat het in andere opzichten het beeld ernstig verstoort. De verdeling over provincies komt sterk overeen met het landelijk beeld. De verdeling over provincies lijkt bij benadering wel representatief te zijn. Drenthe lijkt licht oververtegenwoordigd te zijn in beide steekproeven, maar niet zodanig dat het tot een significant vertekening van de resultaten zou kunnen leiden.

TABEL 2.3 Deelnemers naar denominatie school

\begin{tabular}{|c|c|c|c|}
\hline & po ouders & po leerlingen & Landelijk (DUO) \\
\hline Openbaar & $35,1 \%$ & $34,1 \%$ & $31,1 \%$ \\
\hline Rooms-Katholiek & $26,4 \%$ & $29,1 \%$ & $24,6 \%$ \\
\hline Protestants-Christelijk & $23,0 \%$ & $25,1 \%$ & $34,4 \%$ \\
\hline Overig bijzonder & $15,5 \%$ & $11,7 \%$ & $9,6 \%$ \\
\hline Algemeen Bijzonder & $1,2 \%$ & $0,7 \%$ & $4,8 \%$ \\
\hline Reformatorisch & $2,7 \%$ & $3,3 \%$ & $2,5 \%$ \\
\hline Gereformeerd Vrijgemaakt & $3,8 \%$ & $5,0 \%$ & $1,0 \%$ \\
\hline Antroposofisch & $1,4 \%$ & $0,3 \%$ & $0,1 \%$ \\
\hline Islamitisch & $0,1 \%$ & $0,0 \%$ & $0,9 \%$ \\
\hline Joods & $0,0 \%$ & $0,0 \%$ & $0,0 \%$ \\
\hline Hindoeistisch & $0,0 \%$ & $0,0 \%$ & $0,1 \%$ \\
\hline Evangelisch & $0,4 \%$ & $0,0 \%$ & $0,1 \%$ \\
\hline Evangelische broedergemeenschap & $0,0 \%$ & $0,0 \%$ & $0,0 \%$ \\
\hline Interconfessioneel & $0,7 \%$ & $0,7 \%$ & $0,1 \%$ \\
\hline Samenwerkingsschool & $1,2 \%$ & $0,0 \%$ & $0,0 \%$ \\
\hline Anders & $3,9 \%$ & $1,7 \%$ & $0,0 \%$ \\
\hline N & 812 & 299 & - \\
\hline
\end{tabular}

Tabel 2.3 laat zien hoe de deelnemers verdeeld zijn over denominaties van de scholen waar de kinderen op zitten. De overgrote meerderheid van de kinderen zitten op een Openbare, Rooms-Katholieke of Protestants-Christelijke school. Ten opzichte van populatieaandelen is het Protestants-Christelijke onderwijs licht ondervertegenwoordigd, en het Rooms-Katholieke onderwijs licht oververtegenwoordigd. Bij de kleine denominaties is het Gereformeerd Vrijgemaakte onderwijs oververtegenwoordigd en het 
Algemeen Bijzondere onderwijs ondervertegenwoordigd. ${ }^{2}$ De afwijkingen van representativiteit zijn echter niet van een omvang waarvan ernstige vertekeningen in de resultaten te verwachten zouden zijn.

Tabel 2.4 laat zien hoeveel van de scholen waar de kinderen op zitten een bijzondere pedagogische-didactische aanpak of visie kennen. Dit is meestal niet het geval: ongeveer twee derde van de po-ouders en -leerlingen geven aan dat hun kind c.q. zij zelf op een school zit met geen bijzondere aanpak. De aanpakken die het vaakst voorkomen zijn Dalton, Montessori, Jenaplan en Ontwikkelingsgericht onderwijs. Een tamelijk grote groep geeft aan dat er een andere visie van toepassing was. Veelal ging het om kenmerken waarop een school zich profileert, zoals een nadruk op ICT, cultuur of sport, maar die meestal nog niet gezien worden als een specifieke pedagogisch-didactische visies.

TABEL 2.4 Heeft de school een bijzondere pedagogisch-didactische visie?

\begin{tabular}{|l|r|r|}
\hline & po ouders & po leerlingen \\
\hline Nee het is een reguliere school & $64,7 \%$ & $69,6 \%$ \\
\hline Ja, namelijk & & \\
\hline Montessorischool & $2,1 \%$ & $1,6 \%$ \\
\hline Daltonschool & $6,7 \%$ & $4,2 \%$ \\
\hline Jenaplanschool & $3,5 \%$ & $4,5 \%$ \\
\hline Ontwikkelingsgericht onderwijs & $5,5 \%$ & $2,2 \%$ \\
\hline Nieuw leren/natuurlijk leren & $0,2 \%$ & $1,6 \%$ \\
\hline Steve JobsSchool & $0,0 \%$ & $0,3 \%$ \\
\hline Ervaringsgericht onderwijs & $0,4 \%$ & $0,6 \%$ \\
\hline Freinet & & $15,4 \%$ \\
\hline Anders & $17,0 \%$ & 312 \\
\hline N & & 825 \\
\hline
\end{tabular}

Het ligt voor de hand dat het geloof bij sommige mensen een rol speelt bij de keuze voor een bepaalde school. Aan de ouders is daarom een aantal vragen gesteld over geloof. ${ }^{3}$ Aan de hand hiervan zijn de ouders ingedeeld in drie brede categorieën: mensen waarvoor godsdienst belangrijk is, mensen die godsdienstig zijn maar dat niet zo belangrijk vinden, en mensen die niet godsdienstig zijn. Tabel 2.5 laat de verdeling hiervan zien, voor alle ouders, en apart per denominatie van de school waar het kind op zit. Hieruit blijkt dat ruimt twee derde van alle deelnemende ouders niet godsdienstig is. Voor zover als ze dat wel zijn, blijken ze daar veel waarde aan te hechten. Vooral ouders met een kind op een Protestants-Christelijke of een Overige Bijzondere school zijn relatief vaak godsdienstig, en hechten daar ook relatief veel waarde daaraan. Opvallend is dat er rela-

2 Respondenten die "anders" antwoordden gaven in een open vraag een specificatie hiervan. Hieruit bleek dat het onderscheid tussen denominatie (in de vragenlijst aangeduid als richting) en visie niet voor iedereen helder was, en dat sommige mensen aanduidingen gebruikten die afweken van de officiële benaming. Antwoorden zoals "Jenaplan" en "Christelijk" waren hier vaak aangetroffen.

3 Vooraf werd besloten dat dergelijke vragen te belastend zouden kunnen zijn voor leerlingen. 
tief weinig verschil is tussen ouders met een kind op een Openbare versus een RoomsKatholieke school. Ouders met een kind op een Rooms-Katholieke school zijn iets vaker godsdienstig, maar dit betreft relatief vaak mensen die dit niet zo belangrijk vinden.

TABEL 2.5 Belang dat aan godsdienst wordt gehecht, naar denominatie school

\begin{tabular}{|l|r|r|r|r|r|r|}
\hline & Openbaar & $\begin{array}{r}\text { Rooms- } \\
\text { Katholiek }\end{array}$ & $\begin{array}{r}\text { Protestants- } \\
\text { Christelijk }\end{array}$ & $\begin{array}{r}\text { Overig } \\
\text { bijzonder }\end{array}$ & po-totaal \\
\hline godsdienst belangrijk & $6,5 \%$ & $9,5 \%$ & $41,4 \%$ & $48,2 \%$ & $21,4 \%$ \\
\hline godsdienstig maar niet zo belangrijk & $5,3 \%$ & $12,6 \%$ & $11,8 \%$ & $7,3 \%$ & $8,9 \%$ \\
\hline niet godsdienstig & $88,2 \%$ & $77,9 \%$ & $46,7 \%$ & $44,5 \%$ & $69,6 \%$ \\
\hline
\end{tabular}

\subsection{DUO-analyses}

Naast het vignetonderzoek is ook een analyse uitgevoerd met gegevens uit de door DUO beheerde leerlingenregistraties. Door feitelijke schoolkeuzes te relateren aan alternatieve mogelijkheden binnen dezelfde buurt, is nagegaan in hoeverre de betrokkenen blijk geven van een sterke voorkeur voor scholen met een bepaald profiel. Het achterliggende idee hierbij is dat, als de ouders en/of leerlingen geen duidelijke voorkeur voor bepaalde scholen hebben, de schoolkeuze in hoge mate bepaald zal worden door de afstand tot een school.

Om de afstanden accuraat uit te kunnen rekenen was essentieel dat we redelijk precies konden vaststellen waar een leerling woont. Op basis van de 6-digit-postcode kunnen $x$ - en $y$-coördinaten vastgesteld worden die de woonlocatie en de locatie van de school vrij nauwkeurig benaderen. Deze coördinaten zijn gebruikt om de afstand te berekenen tussen het woonadres en het adres van de school waar de leerling op zit. Afstanden naar alle scholen in de omgeving van het woonadres zijn ook berekend. Op basis van deze gegevens is de afstand naar de dichtstbijzijnde school bepaald, en door dit af te trekken van de feitelijk gereisde afstand wordt per leerling bepaald hoeveel verder men naar school reist dan nodig zou zijn wanneer men de dichtstbijzijnde school zou hebben gekozen. Daarnaast is een aanvullende indicator ontwikkeld dat in de nadere analyses is gebruikt zijn: het aantal scholen binnen een straal van 5 kilometer van het huisadres (een maat voor scholendichtheid in de buurt).

Het bestand dat door DUO is geleverd bevat tevens een aantal andere kenmerken, die worden gebruikt bij het nader analyseren van de voorkeuren:

- geslacht

- geboorteland van de leerling en zijn ouders

- etniciteit (autochtoon + westerse en niet-westerse allochtoon naar landengroep)

- brinnummer (het nummer van de school)

- vestigingsnummer (van scholen die meerdere vestigingen kennen) 
- leerlinggewicht

- leerjaar

Om veranderingen in voorkeuren in de tijd vast te kunnen stellen zijn gegevens van inschrijvingsjaren 2010 t/m 2015 geanalyseerd. 



\section{3 \\ DIRECTE VERGELIJKINGEN TUSSEN DENOMINATIES}

In het huidige Nederlandse onderwijsstelsel heeft de stichting van bijzondere scholen betrekking op denominaties. Als een startpunt voor de analyse kijken we in deze paragraaf daarom naar de voorkeur voor denominaties, zonder tussenkomst van andere attributen die de keuze mede zouden kunnen bepalen. In aanloop tot de vraag naar deze voorkeuren zijn ouders gevraagd of ze, naast de denominatie van de school waar hun kind nu op zit, zich aangesproken voelen door een andere denominatie. Dit biedt een eerste indicatie van hoezeer men bewust is van andere denominaties als mogelijke alternatief. Tabel 3.1 laat zien hoe de ouders op deze vraag hebben geantwoord. Vanwege de beperkte aantallen ouders met een kind op scholen met denominaties anders dan Openbaar, Protestants-Christelijk en Rooms-Katholiek, worden deze andere denominaties samengebundeld onder "Overig Bijzonder".

TABEL 3.1 Is er een andere denominatie die u aanspreekt?

\begin{tabular}{|l|r|r|r|r|r|r|}
\hline Nee, & Openbaar & $\begin{array}{r}\text { Rooms- } \\
\text { Katholiek }\end{array}$ & $\begin{array}{r}\text { Protestants- } \\
\text { Christelijk }\end{array}$ & $\begin{array}{r}\text { Overig } \\
\text { bijzonder }\end{array}$ & Totaal \\
\hline Ja, namelijk: & $77,5 \%$ & $40,2 \%$ & $50,8 \%$ & $46,8 \%$ & $56,8 \%$ \\
\hline $\begin{array}{l}\text { Openbaar } \\
\text { Rooms-Katholiek }\end{array}$ & nvt & $45,3 \%$ & $20,9 \%$ & $17,5 \%$ & $19,5 \%$ \\
\hline $\begin{array}{l}\text { Protestants-Christelijk } \\
\text { Overig bijzonder }\end{array}$ & $8,4 \%$ & $\mathrm{nvt}$ & $3,2 \%$ & $4,8 \%$ & $4,4 \%$ \\
\hline
\end{tabular}

Ouders met een kind op een Openbare school lijken weinig geïnteresseerd te zijn in scholen met een bijzondere denominatie. Bijna de helft van de ouders met een kind op een Rooms-Katholieke school vindt een Openbare school een interessant alternatief. Openbare scholen zijn ook voor een substantieel deel van de ouders met een kind op een Protestants-Christelijke of een Overig Bijzonder school een reële optie. Verder zijn Protestants-Christelijke en Overige Bijzondere scholen over en weer vaak genoemde alternatieven. Van de grote denominaties worden over de hele linie Rooms-Katholieke scholen het minst vaak genoemd als interessant alternatief. 


\section{Keuze tussen specifieke denominatie-paren}

Men is vervolgens gevraagd om de eigen denominatie te vergelijken met andere denominaties (waaronder voor het gemak het Openbaar onderwijs ook wordt gerekend). Hiermee ontstaat een maat waarmee de relatieve voorkeuren voor verschillende denominaties uitgedrukt worden in termen van de afstand die men hun kind extra zou willen laten reizen om naar een school met een bepaalde denominatie te laten gaan, in plaats van een school met een specifieke andere denominatie. Ter illustratie staan in figuur 3.1 de voorkeuren voor Rooms-Katholieke versus Protestants-Christelijke onderwijs.

FIGUUR 3.1 Relatieve onderlinge voorkeuren voor Rooms-Katholieke versus Protestants-Christelijke scholen, uitgedrukt in extra afstand die met eventueel bereid is hun kind te laten reizen $(\mathrm{N}=802)$

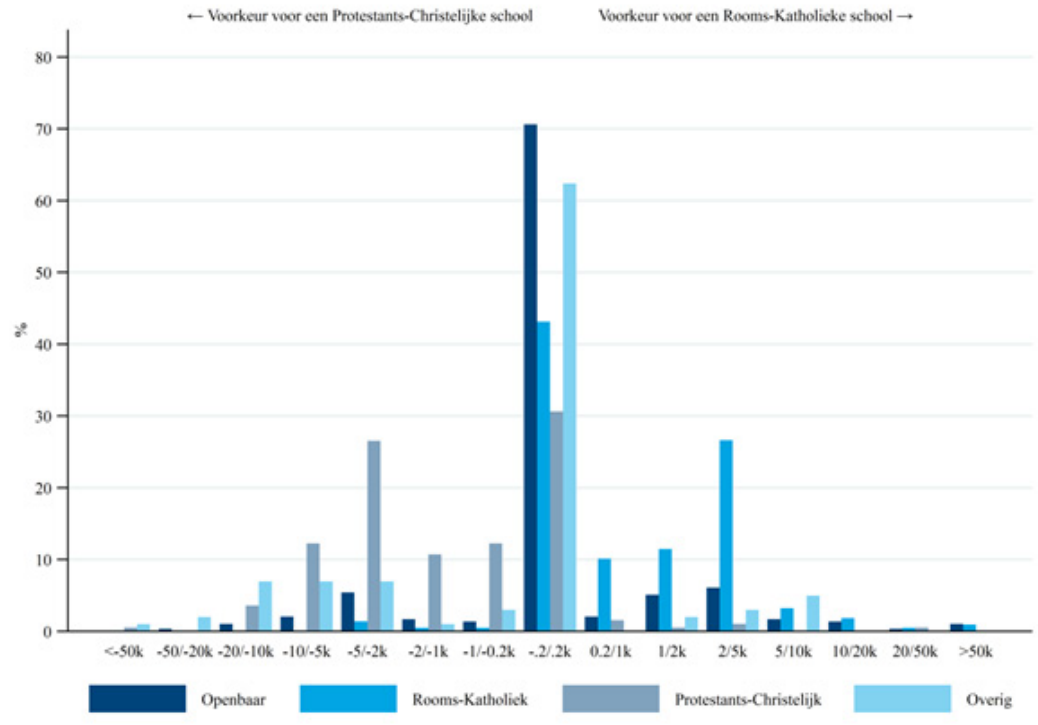

Een aantal dingen valt meteen op uit figuur 3.1. Ten eerste, een fors deel van de respondenten geeft aan dat ze hun kind helemaal niet verder te willen laten reizen voor de ene of de andere denominatie (afstand "o", middenin de grafiek). Dit geldt vooral voor de ouders met een kind op een Openbare of Overige Bijzondere school, die buiten de directe vergelijking vallen. Maar ook een fors deel van de ouders met een kind op een Rooms-Katholieke of Protestants-Christelijke school, is indifferent tussen de eigen en de alternatieve denominatie. Dit geldt voor bijna een derde van de ouders met een kind op een Protestants-Christelijke school, en maar liefst $43 \%$ van de ouders met een kind op een Rooms-Katholieke school.

Als ouders wel bereid zijn om hun kind te laten reizen gaat de voorkeur meestal in de richting van de eigen denominatie. Ongeveer $12 \%$ van de ouders met een kind op een Protestants-Christelijke school is bereid om hun kind 0,2 tot $1 \mathrm{~km}$ verder te laten reizen 
om niet naar een Rooms-Katholieke school te hoeven gaan, en een iets kleiner percentage zou hun kind hiervoor 1 tot 2 kilometer verder willen laten reizen. Ruim een kwart zou hun kind 2 tot $5 \mathrm{~km}$ verder willen laten reizen hiervoor. Deze percentages worden nagenoeg weerspiegeld aan de rechterkant van figuur 3.1 door ouders met een kind op een Rooms-Katholieke school. Wel ligt het percentage ouders dat hun kind desnoods meer dan 5 kilometer extra zou willen laten reizen hoger aan de Protestants-Christelijke dan aan de Rooms-Katholieke kant: $15 \%$ versus 5\%.

Opvallend is dat een klein maar niet verwaarloosbaar deel van de ouders bereid is om hun kind verder te laten reizen om naar een school met de andere denominatie te gaan. Dit zou kunnen betekenen dat de ouders van mening zijn veranderd sinds ze de school voor hun kind kozen, maar ook dat men destijds een pragmatische keuze heeft gemaakt, omdat er geen school met de geprefereerde denominatie in de buurt van hun huis was.

Een vergelijkbaar beeld komt naar voren wanneer we Openbaar onderwijs contrasteren met Protestants-Christelijke en Rooms-Katholieke onderwijs. Dit ligt anders wanneer we de kleinere denominaties bekijken. Figuur 3.2 zoomt bij wijze van voorbeeld in op het Gereformeerd Vrijgemaakte en het Reformatorische onderwijs, en contrasteert dit met het Openbare onderwijs.

FIGUUR 3.2 Relatieve voorkeuren voor Openbare scholen tegenover Gereformeerd Vrijgemaakte en Reformatorische scholen, uitgedrukt in extra afstand die met eventueel bereid is hun kind te laten reizen $(\mathrm{N}=802)$

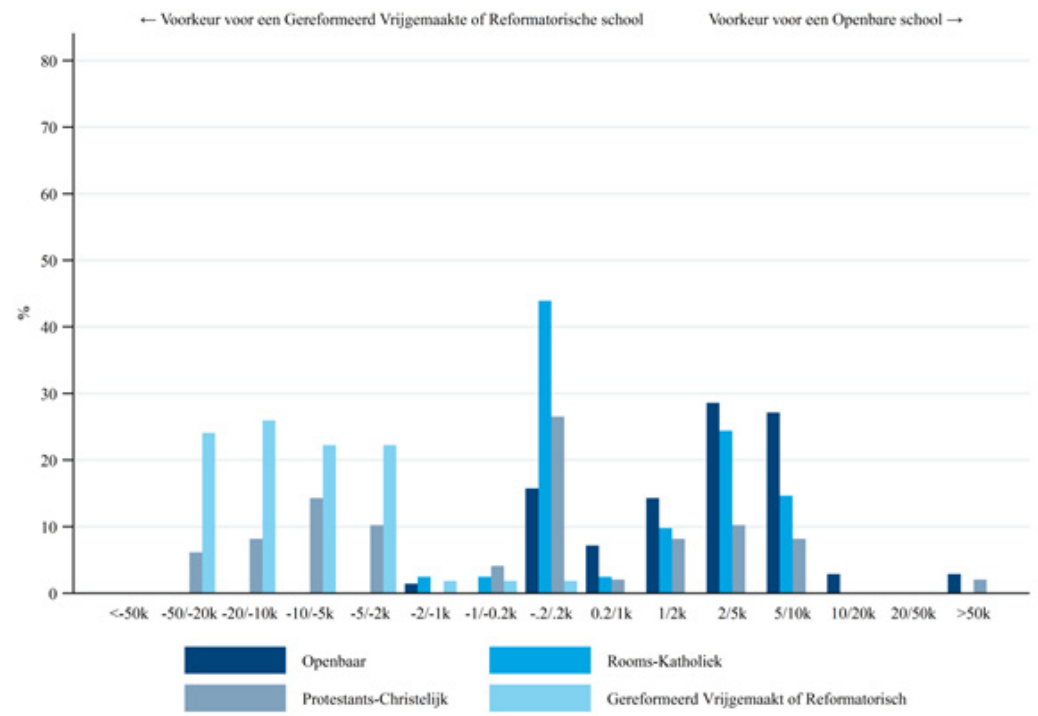

Opvallend is het feit dat ouders met een kind op een Protestants-Christelijke school als enigen verdeeld lijken te zijn in hun voorkeuren, waarbij een aanzienlijk deel bereid 
is hun kind fors extra te laten reizen om naar een Openbare school te gaan in plaats van naar een Gereformeerd Vrijgemaakte of Reformatorische school, terwijl een iets groter deel bereid zou zijn hun kind tamelijk ver te laten reizen om het omgekeerde te bewerkstelligen. Verder blijkt een deel van de ouders met een kind op een Openbare of Rooms-Katholieke school geen uitgesproken voorkeur te hebben tussen deze opties voor hun kind, maar slechts een klein percentage van deze ouders zou hun kind verder willen laten reizen voor een Gereformeerd Vrijgemaakte of Reformatorische school, en een meerderheid zou hun kind verder willen laten reizen voor het omgekeerde. Bijna alle ouders met een kind op een Gereformeerd Vrijgemaakte of Reformatorische school zouden bereid zijn hun kind verder te laten reizen om deze situatie te handhaven in plaats van ze naar een Openbare school te hoeven sturen. Nadere analyses laten zien dat Vrije scholen ook relatief vaak een positieve voorkeur genieten ten opzichte van Protestants-Christelijke en Rooms-Katholieke scholen, en dat vooral bij het Islamitische en Hindoeïstische onderwijs veel respondenten bereid zijn hun kind ver te laten reizen om niet naar zo'n school te hoeven gaan.

\section{Een algemene voorkeursmaat}

Op basis van deze informatie over de manier waarop men verschillende denominaties tegen elkaar afweegt, kan een algemene indicator worden gemaakt over het belang van denominatie bij de keuze. Als eerste stap hiertoe bepalen we voor iedere respondent welke denominatie door hen het meest geprefereerd wordt. Meestal is dit de feitelijke denominatie van de school waar het kind op zit, maar in een aantal gevallen geven respondenten aan dat ze liever hun kind op een school met een andere denominatie zou willen hebben. Voor deze meest geprefereerde denominatie wordt vervolgens bekeken wat de gemiddelde extra afstand is die men hun kind zou willen laten afleggen om deze voorkeur te realiseren ten opzichte van andere denominaties. Wanneer de gemiddelde afstand groot is, betekent dit dat men denominatie erg belangrijk vindt. Wanneer het erg kort of zelfs nul is, betekent dit dat denominatie er weinig toedoet bij de keuze voor een school. Figuur 3.3 geeft de verdeling van deze voorkeuren aan, apart voor de drie grote denominaties en voor de Overig Bijzondere denominaties samen.

Omdat het referentiekader nu de meest geprefereerde denominatie is, zijn alle afstanden positief of nul. Uit de figuur blijkt dat een deel van de respondenten met Openbaar, Rooms-Katholiek of Protestants-Christelijk onderwijs als meest geprefereerde optie, niet bereid is om hun kind hiervoor substantieel verder te laten reizen. Dit geldt voor $9 \%$ van de ouders met Openbaar als meest geprefereerde optie, en bijna 15\% van de ouders die hun kind het liefst op een Rooms-Katholieke of Protestants-Christelijke school zou willen hebben. De overgrote meerderheid van deze groepen ouders zou echter hun kind 200 meter tot 5 kilometer extra willen laten reizen. Ouders met een kind op een Openbare of Protestants-Christelijke school zijn iets vaker bereid hun kind verder te laten reizen dan ouders met een kind op een Rooms-Katholieke school. De grootste bereidheid om kinderen extra te laten reizen vinden we echter bij ouders met een kind op een Overig Bijzondere school. Weinig ouders die één van deze denominaties als meest geprefereerd heeft zou hiervoor hun kind niet willen laten reizen, en meer dan de helft zou hun kind 
$5 \mathrm{~km}$ of meer verder willen laten reizen om deze voorkeur te realiseren ten opzichte van de andere denominatie. De betreffende groep ouders met een kind op een Overig Bijzondere school is echter kleiner dan de drie andere groepen. Hierdoor is de totale verdeling van de afstand die men hun kind wil laten afleggen om de meest geprefereerde denominatie te realiseren iets minder gespreid dan de figuur suggereert.

FIGUUR 3.3 Afstand dat men bereid is te extra te reizen voor de meest geprefereerde denominatie t.o.v. andere denominaties, naar meest geprefereerde denominatie

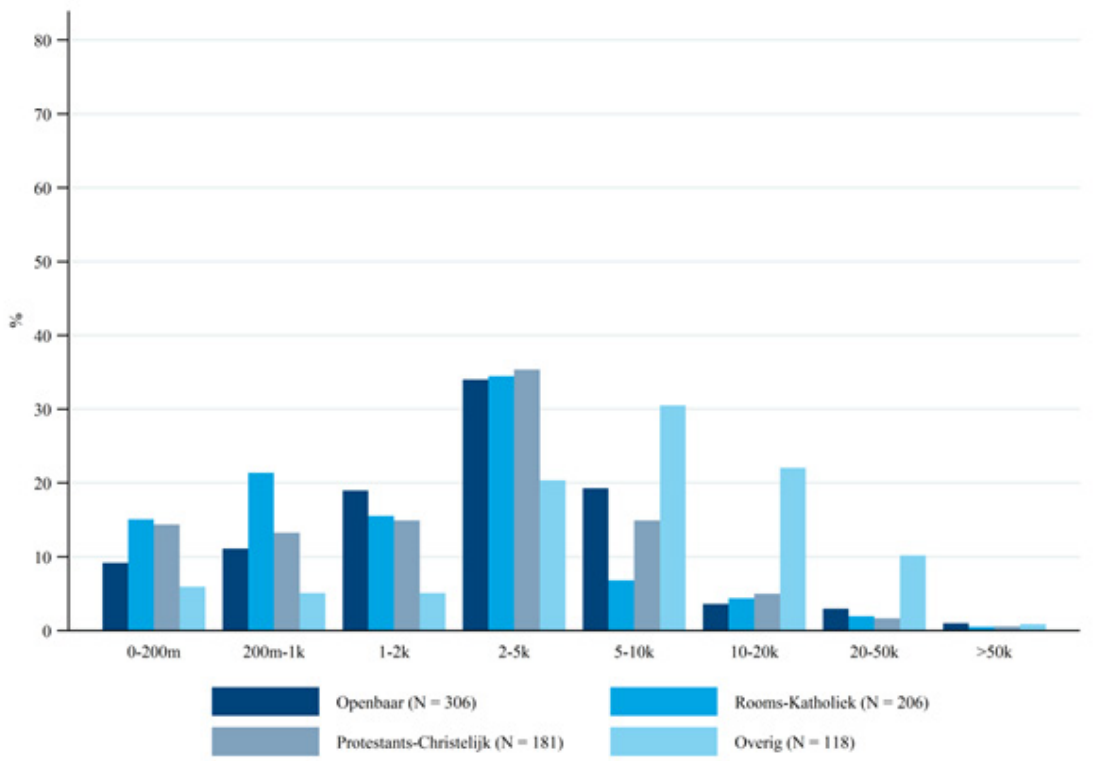

Dit zien we in figuur 3.4, waar het onderscheid naar denominatie wordt losgelaten. In deze figuur wordt de bereidheid om te reizen voor de meest geprefereerde denominatie in het algemeen gepresenteerd, ongeacht wat deze specifieke voorkeur is. Dit levert een algemene maat op van de voorkeur voor denominatie. Hieruit blijkt dat deze voorkeuren een tamelijk grote spreiding kennen. Aan de ene kant zitten ongeveer $11 \%$ van ouders die niet of nauwelijks bereid zijn hun kind te laten reizen om hun voorkeursdenominatie te realiseren. Aan het andere uiterste zit een kleine groep ouders die hun kind desnoods meer dan 50 kilometer hiervoor zouden willen laten reizen. De meeste ouders zitten uiteraard hier tussen in. Zo'n 13\% vindt denominatie niet onbelangrijk, maar zou hun kind niet meer dan 1 kilometer hiervoor extra willen laten reizen. Ongeveer de helft van de ouders heeft een veel uitgesprokener voorkeur voor denominatie, en deze ouders zouden hun kinderen 2 tot 10 kilometer verder willen laten reizen. Ongeveer $10 \%$ van alle ouders zouden hun kinderen meer dan 10 kilometer extra laten reizen, wat op te vatten is als een erg sterke voorkeur. 
FIGUUR 3.4 Afstand die men bereid is te extra te reizen voor de meest geprefereerde denominatie t.o.v. andere denominaties, alle denominaties samen $(\mathrm{N}=802)$

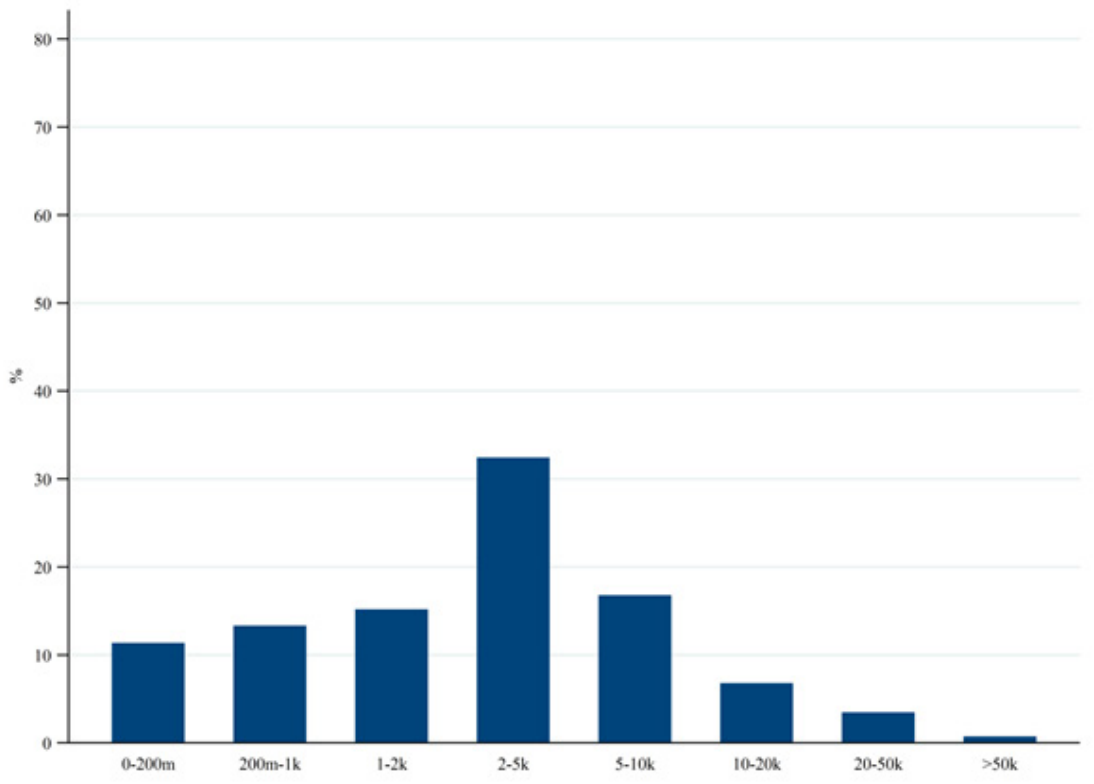

\subsection{Voorkeur en aanbod}

Een belangrijke vraag is of de specifieke voorkeuren die ouders hebben het lastig voor hen maken om hun kind op de school van hun voorkeur te krijgen. In principe is het voor alle ouders mogelijk om hun kind op een school van de gewenste denominatie te krijgen, maar de reisafstand die daar mee gemoeid is, kan deze keuze feitelijk toch in de weg staan. Zoals hierboven reeds is beschreven kan daarom de afstand die een kind moet reizen worden gezien als de prijs die betaald wordt om een voorkeur te realiseren. De afstand die ouders hun kind zouden willen laten reizen is in deze metafoor dan de prijs die men bereid is te betalen.

Net als in andere markten wordt de betaalde prijs bepaald door de samenkomst van vraag en aanbod. Bij een gevarieerd aanbod dicht bij de deur zal de prijs meestal laag zijn, en zal men meestal hun kind niet ver hoeven te laten reizen. Ook wanneer men geen uitgesproken voorkeur heeft voor een bepaalde denominatie zal men hun kind meestal niet zo ver hoeven te laten reizen, zolang als er een school in de buurt is die verder aan de minimale verwachtingen voldoet. In dat geval is de prijs dus ook laag. Anders ligt het bij een beperkt aanbod. Als men een voorkeur voor een bepaalde school heeft, en de reisafstand is groot, dan zijn de kosten om deze wens te realiseren hoog. Als de betreffende school verder weg is dan men bereid is om extra te reizen, dan zal men kiezen voor een school met een ander profiel. Naast de reisafstand naar de school 
die wel wordt gekozen kan dan ook het niet kunnen realiseren van de gewenste schoolkeuze als een additionele kostenpost worden gezien.

Aan de hand van een voorbeeld kan dit duidelijk worden gemaakt.

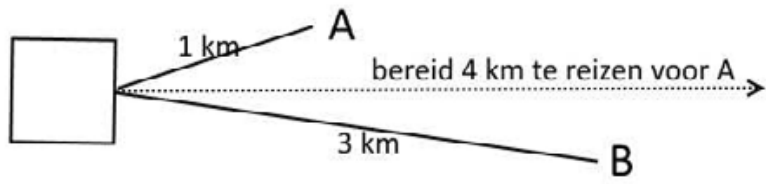

In dit voorbeeld woont iemand op 1 kilometer van een school met denominatie A en 3 kilometer van een school met denominatie $B$. Als deze persoon een voorkeur heeft voor denominatie $A$, en bereid is om 4 kilometer hiervoor te reizen, dan zal hij kiezen voor $A$, omdat die school immers beschikbaar is binnen de afstand die hij bereid is te reizen. De persoon moet dus 1 kilometer reizen om zijn voorkeur te realiseren. De kosten voor deze persoon zijn dus $1 \mathrm{~km}$.

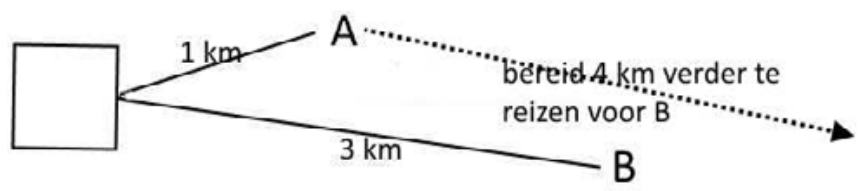

Als in dezelfde situatie iemand anders een voorkeur heeft voor $B$, en bereid is om 4 kilometer hiervoor verder te reizen, dan zal deze persoon naar B gaan. Ook hier bestaan de kosten uit de werkelijk afgelegde afstand, in dit geval 3 kilometer. 


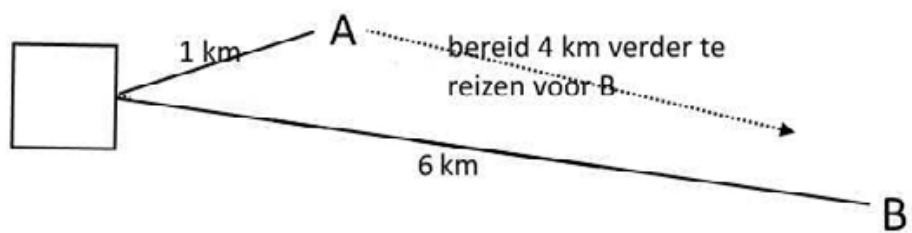

Als school B echter op 6 kilometer zou liggen, dan zou deze persoon, hoewel zijn voorkeur naar B uitgaat, toch voor A kiezen. B is te ver weg. In dit geval is de berekening van de kosten iets complexer. De kilometer die hij feitelijk reist telt ook hier als een kostenpost. Deze persoon betaalt echter ook een additionele prijs omdat hij zijn werkelijke voorkeur niet kan realiseren. Dit verlies bestaat uit de 4 kilometer verder die hij had willen reizen ten opzichte van school A. De totale kosten voor deze persoon zijn dus $1+4=5$ kilometer.

Voor de respondenten van het onderzoek is op deze wijze onderzocht in hoeverre het bestaande schoolaanbod in hun omgeving de mogelijkheid verschaft hun voorkeur qua denominatie te realiseren. Tabel 3.2 geeft hiervan een overzicht. Hierin worden de verschillende kostencomponenten uiteengezet met gebruik van het gemeenschappelijke meetlat afstand, waarbij steeds verschillende scenario's in beschouwing worden genomen, bestaande uit de mensen die tot de eerste $1 \%, 10 \%, 50 \%, 90 \%$ en $99 \%$ behoren in termen van afstand.

TABEL 3.2 De verdeling van reisafstanden naar school bij verschillende scenario's

\begin{tabular}{|l|r|r|r|r|r|}
\hline & $1 \%$ & $10 \%$ & $50 \%$ & $90 \%$ & $99 \%$ \\
\hline Dichtstbijzijnde school & 35 meter & 124 meter & 359 meter & 740 meter & $2,1 \mathrm{~km}$ \\
\hline Feitelijke afstand & 58 meter & 178 meter & 559 meter & $2,3 \mathrm{~km}$ & $19,8 \mathrm{~km}$ \\
\hline \begin{tabular}{l|r|r|r|} 
Voorkeursdenominatie \\
Afstand bij afweging tussen aanbod \\
en voorkeur
\end{tabular} & 41 meter & 165 meter & 514 meter & $2,1 \mathrm{~km}$ & $21,8 \mathrm{~km}$ \\
\hline Totale kosten & 41 meter & 160 meter & 490 meter & $1,4 \mathrm{~km}$ & $6,1 \mathrm{~km}$ \\
\hline
\end{tabular}

Allereerst geldt voor de meeste mensen dat ze zelfs als hun kind de dichtstbijzijnde school bezoekt, er gereisd moet worden. 1\% van de ouders woont op minder dan 35 meter van de dichtstbijzijnde school. De helft van de ouders heeft binnen 359 meter een school. Maar $1 \%$ van de respondenten moet verder dan 2,1 km reizen voor de eerste school. Wanneer men niet voor de dichtstbijzijnde school kiest zijn de feitelijk afstanden langer dan dit (tweede rij in tabel 3.2). Hierbij speelt zowel de voorkeur voor een denominatie als de voorkeur voor andere kenmerken een rol. Sommige leerlingen wonen zeer ver van hun school. 
Als vervolgens bekeken wordt hoe ver men moet reizen voor een school met de denominatie van de grootste voorkeur dan lopen de afstanden ten opzichte van de dichtstbijzijnde school vooral aan de bovenkant van de verdeling wat op. 10\% van de respondenten zou 2,1 km moeten reizen voor de eerste school van de voorkeurdenominatie en $1 \%$ zou meer dan $21,8 \mathrm{~km}$ moeten reizen. Ouders die geen grote voorkeur voor hun voorkeursdenominatie hebben, zullen wellicht ervoor kiezen om deze afstand niet af te leggen, maar in plaats daarvan een school met een andere denominatie te kiezen die dichter bij huis is.

In de vierde rij staat aangegeven wat de verdeling van de reisafstanden zou zijn, als ouders op basis van het aanbod en de door hen aangegeven voorkeuren een school zouden kiezen. Met name de lange afstanden reduceren ten opzichte van de afstand tot de school met de voorkeursdenominatie. $10 \%$ van de ouders reist meer dan 1,4 kilometer en 1\% meer dan 6,1 kilometer. Dat zijn aanzienlijke reducties ten opzichte van de afstand die men had moeten reizen om wel een school met de denominatie van voorkeur te bereiken. De prijs van deze kortere afstand is dat men hun kind naar een school stuurt die niet de denominatie van voorkeur heeft. De afstand die men verder had willen reizen, kan gezien worden als de kosten voor deze concessie. Als deze worden toegevoegd aan de berekening, zijn de kosten voor $10 \%$ van de ouders 2,0 kilometer en voor $1 \% 10,1$ kilometer.

Het valt overigens te verwachten dat de omvang van de keuze die ouders hebben door de huidige leerlingendaling zal worden verminderd. Deze daling zal immers ertoe leiden dat sommige scholen moeten sluiten, waardoor voor sommige ouders scholen in de buurt met hun voorkeursdenominatie wegvallen. Deze ontwikkeling leidt tot hogere kosten voor deze ouders, omdat ze óf hun kind verder moeten laten reizen, óf genoegen moeten nemen met een school met een andere denominatie. 



\section{4 \\ VIGNETTENANALYSES}

In de vorige paragraaf is gekeken naar de voorkeuren van ouders voor scholen met een bepaalde denominatie, zonder dat daarbij andere kenmerken worden meegenomen. In deze paragraaf wordt gekeken naar de voorkeuren voor verschillende attributen waaronder denominatie, maar ook onder andere pedagogische aanpak, onderwijskwaliteit en bijzonder profileringskenmerken van scholen - waarbij deze simultaan aan de ouders worden voorgelegd. Deze voorkeuren, die door middel van een vignettenanalyse worden berekend, stellen ons in staat om een veel completer beeld te schetsen van de diversiteit aan kenmerken die door ouders worden gewaardeerd, en hoeveel de waardering voor scholen nog kan toenemen op basis van deze andere kenmerken. In eerste instantie bespreken we de resultaten voor de ouders. We komen later in de paragraaf kort terug op de resultaten voor de kinderen.

\section{Voorkeuren denominaties}

Tabel 4.1 geeft een overzicht van de afstanden die men hun kind extra zou willen laten afleggen om hun meest geprefereerde denominatie te realiseren, relatief tot de op-eenna meest geprefereerde denominatie. We geven de afstanden apart weer per denominatie. Let wel: het gaat hier om de denominatie die uit de analyses als meest geprefereerd naar voren komt; dit is niet per se gelijk aan de denominatie van de school waar het kind feitelijk op zit. We tonen verschillende percentielen, die de voorkeuren aangeven voor ouders afhankelijk van hun plaats in de verdeling bij de betreffende denominatie. Bijvoorbeeld, $10 \%$ van de ouders met Openbaar als meest geprefereerde optie zou hun kind hiervoor niet meer dan 0,3 kilometer verder willen laten reizen ten opzichte van de op-een-na meest geprefereerde denominatie. Een kwart van deze ouders wil hun kind hiervoor maximaal 1 kilometer verder laten reizen. Voor de helft is 2,1 kilometer het maximum, en voor $90 \% 4,9$ kilometer. Uiteindelijk is $1 \%$ van deze ouders bereid hun kind hiervoor meer dan 9,7 kilometer extra te laten reizen. 
TABEL 4.1 Verdeling bereidheid om extra te reizen naar een school van de meest geprefereerde denominatie in vergelijking met een school van de op-een-na meest geprefereerde denominatie $(\mathrm{N}=802)$

\begin{tabular}{|l|r|r|r|r|r|r|r|}
\hline Meest geprefereerde denominatie & 10e perc. & 25e perc. & 50e perc. & 75e perc. & 90e perc. & 99e perc. \\
\hline Openbaar & & & & & \\
\hline Protestants-Christelijk & 0,3 & 1,0 & 2,1 & 3,5 & 4,9 & 9,7 & 186 \\
\hline Rooms-Katholiek & 0,3 & 0,7 & 1,8 & 4,0 & 6,1 & 8,6 & 123 \\
\hline Algemeen Bijzonder & 0,2 & 0,5 & 1,4 & 2,7 & 4,2 & 7,8 & 85 \\
\hline Evangelisch & 0,2 & 0,4 & 0,7 & 1,2 & 2,9 & 5,8 & 29 \\
\hline Evangelische Broedergemeenschap & 0,2 & 0,6 & 1,2 & 3,2 & 5,6 & 7,5 & 87 \\
\hline Gereformeerd Vrijgemaakt & 0,0 & 0,1 & 0,6 & 1,5 & 1,9 & 2,7 & 21 \\
\hline Hindoeistisch & 0,2 & 0,6 & 1,2 & 3,4 & 5,3 & 7,3 & 101 \\
\hline Interconfessioneel & 0,1 & 0,1 & 0,5 & 2,1 & 2,4 & 2,5 & 13 \\
\hline Islamitisch & 0,0 & 0,4 & 0,7 & 1,1 & 1,5 & 1,9 & 18 \\
\hline Joods & 0,1 & 0,3 & 1,0 & 1,3 & 1,7 & 1,7 & 7 \\
\hline Reformatorisch & 0,0 & 0,1 & 0,5 & 1,0 & 1,2 & 1,3 & 11 \\
\hline VrijeSchool & 0,2 & 0,5 & 1,7 & 3,7 & 5,8 & 10,7 & 72 \\
\hline
\end{tabular}

Uit tabel 4.1 komt naar voren dat er voor ongeveer de helft van de denominaties een groep is die een tamelijk uitgesproken voorkeur hiervoor heeft, uitgedrukt in termen van de afstand die men bereid is om hiervoor te reizen ten opzichte de op één na meest geprefereerde denominatie. Dit geldt voor het Openbare, Protestants-Christelijke en RoomsKatholieke onderwijs, maar ook voor Reformatorische, Evangelische, Gereformeerd Vrijgemaakte en Vrije Scholen. Over de hele linie verschillen deze scholen weinig van elkaar, maar op het $99^{\text {e }}$ percentiel - de groep met de meest uitgesproken voorkeuren blijkt er enige differentiatie. Hierbij tonen ouders met een voorkeur voor Reformatorisch, Openbaar of Protestant-Christelijk onderwijs de grootste bereidheid om verder te reizen. We zien veel minder uitgesproken voorkeuren bij de denominaties Algemeen Bijzonder, Evangelische Broedergemeenschap, Hindoeïstisch, Interconfessioneel, Islamitisch en Joods. Hierbij moet wel als relativerende opmerking worden geplaatst dat de vertegenwoordiging van deze denominaties in de data vrij gering is.

In figuur 4.1 staat een overzicht van de omgerekend afstanden voor po ouders, uitgesplitst naar meest geprefereerde denominatie. Vanwege de kleine aantallen, worden alle Overig Bijzondere denominaties hier bij elkaar gebundeld. 
FIGUUR 4.1 Afstand die men bereid is te extra te reizen voor de meest geprefereerde denominatie t.o.v. de op-een-na meest geprefereerde andere denominatie, naar meest geprefereerde denominatie $(\mathrm{N}=802)$

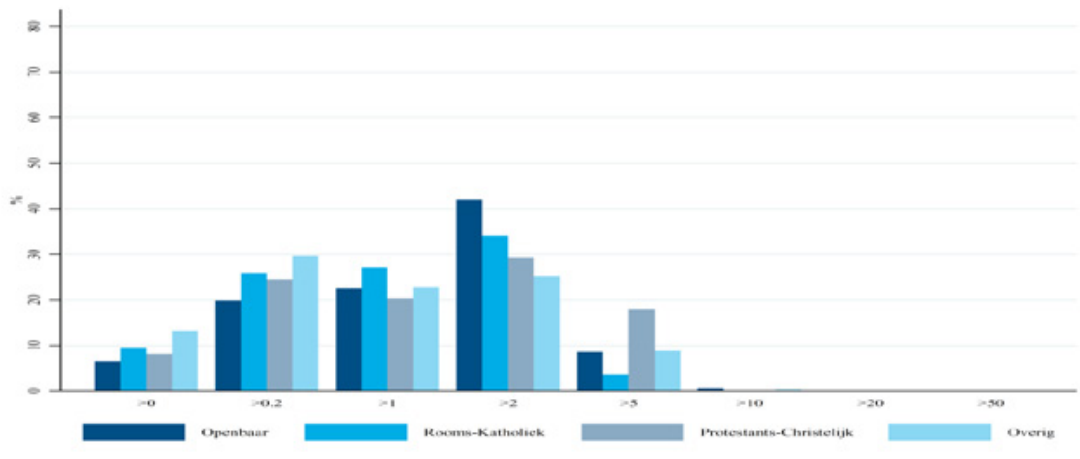

Er is niet zo veel verschil tussen de denominaties in termen van de bereidheid om extra te reizen. Ouders met Openbaar als meest geprefereerde optie zijn relatief vaak bereid om hun kinderen hiervoor iets verder te laten reizen dan ouders die een van de andere denominaties prefereren. Ouders die Overig Bijzonder onderwijs prefereren blijken relatief vaak niet of nauwelijks bereid te zijn om hun kinderen daarvoor ver te laten reizen. In alle categorieën geldt overigens dat er een substantiële minderheid is die niet of nauwelijks bereid is om hun kind extra te laten reizen. Van deze mensen kan worden gezegd dat het plaatsen van hun kind op een school in de meest geprefereerde denominatie hen erg weinig uitmaakt. Er is een iets grotere groep die tot maximaal 1 kilometer bereid is hun kind extra te laten reizen. Van deze mensen kan worden gezegd dat ze wel een duidelijke voorkeur hebben, maar dat dit niet sterk genoeg is om grote offers voor te willen brengen. lets minder dan de helft van de ouders is bereid hun kinderen meer dan twee kilometer verder te laten reizen, maar de meesten willen niet verder gaan dan vijf kilometer extra. Bij deze ouders kan worden gezegd dat ze een tamelijk uitgesproken voorkeur hebben, maar dat dit in termen van afstand nog altijd duidelijk begrensd is. Slechts een klein deel van de ouders is bereid hun kind desnoods meer dan 10 kilometer verder te laten reizen voor de meest geprefereerde denominatie. Daarbij dient wel opgemerkt te worden dat het om enkele tientallen duizenden burgers kan gaan, een zeker niet te verwaarlozen aantal mensen met een zeer sterke voorkeur voor hun meest geprefereerde denominatie.

\section{Voorkeuren andere attributen}

In de volgende tabellen beschrijven we in het kort de uitkomsten met betrekking tot deze attributen. Om te beginnen staat in tabel 4.2 de uitkomsten met betrekking tot de voorkeuren voor de eventuele pedagogische-didactische visie van de school. 
TABEL 4.2 Verdeling bereidheid om extra te reizen naar een school van de meest geprefereerde pedagogische-didactische visie in vergelijking met de op-een-na meest geprefereerde visie $(\mathrm{N}=802)$

\begin{tabular}{|c|c|c|c|c|c|c|c|}
\hline & 10e perc. & 25e perc. & 50e perc. & 75e perc. & 90 e perc. & 99 e perc. & N \\
\hline \multicolumn{8}{|l|}{ Didactische visie } \\
\hline Geen & 0.3 & 1.1 & 2.2 & 4.2 & 5.7 & 9.4 & 209 \\
\hline Dalton & 0.2 & 0.5 & 1.2 & 1.9 & 2.8 & 6.8 & 70 \\
\hline Jenaplan & 0.2 & 0.5 & 1.6 & 2.6 & 3.6 & 5.3 & 95 \\
\hline Montessori & 0.1 & 0.4 & 0.9 & 2.5 & 3.2 & 4.9 & 74 \\
\hline Ervaringsgericht onderwijs & 0.2 & 0.4 & 0.9 & 2 & 2.5 & 5.8 & 41 \\
\hline Freinet & 0.1 & 0.3 & 0.6 & 1.1 & 2.4 & 3.3 & 26 \\
\hline Kees Boeke & 0.1 & 0.1 & 0.4 & 1.3 & 1.3 & 1.7 & 15 \\
\hline Nieuw leren/natuurlijk leren & 0.1 & 0.2 & 0.6 & 1.7 & 3.2 & 5.2 & 121 \\
\hline Ontwikkeling & 0.1 & 0.3 & 0.6 & 1.3 & 2.3 & 5.8 & 98 \\
\hline Steve Jobsschool & 0.2 & 0.3 & 0.8 & 1.9 & 2.4 & 6.2 & 53 \\
\hline
\end{tabular}

Uit tabel 4.2 blijkt dat er bij veel mensen een tamelijk sterke voorkeur is voor scholen met geen expliciete didactische visie. Verder blijkt dat de meeste inhoudelijke visies een "achterban" hebben die bereid is hun kinderen enige extra afstand op te leggen om hun voorkeur op dit punt te realiseren. Net als bij denominaties komen verschillen tussen afzonderlijke visies het sterkst naar voren bij de respondenten met de meest extreme preferenties (de $99^{\mathrm{e}}$ percentiel), en is het verschil voor de overige percentielen niet zo groot. Sterke liefhebbers van Dalton- en Steve Jobsscholen zijn bereid hun kinderen soms vrij ver hiervoor te laten reizen.

Tabel 4.3 toont de coëfficiënten voor de bijzondere kenmerken waarop scholen zich zouden kunnen profileren, naast denominatie en visie. Omdat de in de vignetten opgenomen kenmerken slechts als voorbeelden zijn bedoeld van de type kenmerken waarop hedendaagse scholen zich kunnen profileren wordt het potentieel belang van zulke kenmerken waarschijnlijk onderschat. Het is immers aannemelijk dat een deel van de respondenten meer waarde hecht aan kenmerken die helemaal niet op de vignetten zijn getoond. Wanneer ze hun voorkeur hadden kunnen uitspreken voor deze kenmerken zou min of meer per definitie een groter bereidheid om hiervoor offers te brengen naar voren zijn gekomen.

De meest gewaardeerde kenmerken uit deze lijst zijn "geloof centraal", "prestatiegericht", "creatief" en "gepersonaliseerd leren". Men heeft relatief weinig over voor Leren door spelen, Kunstzinnig onderwijs, Leren met ICT en Onderzoekend leren. 
TABEL 4.3 Verdeling bereidheid om extra te reizen naar een school van de meest geprefereerde bijzonder kenmerk in vergelijking met de op-een-na meest geprefereerde bijzonder kenmerk $(\mathrm{N}=802)$

\begin{tabular}{|l|r|r|r|r|r|r|r|}
\hline Bijzondere kenmerken & 10e perc. & 25e perc. & 50e perc. & 75 e perc. & 90e perc. & 99 e perc. & N \\
\hline Creatief & & & & & & \\
\hline Geloof centraal & 0,2 & 0,5 & 1,3 & 2,0 & 3,4 & 5,5 & 144 \\
\hline Gepersonaliseerd leren & 0,3 & 0,8 & 1,5 & 2,8 & 4,8 & 6,1 & 47 \\
\hline Kunstzinnig & 0,1 & 0,2 & 0,8 & 1,6 & 2,2 & 4,6 & 73 \\
\hline Leren door spelen & 0,1 & 0,2 & 0,4 & 1,3 & 1,6 & 2,7 & 27 \\
\hline Leren met ICT & 0,2 & 0,3 & 0,4 & 0,9 & 1,0 & 2,1 & 21 \\
\hline Muzikaal onderwijs & 0,1 & 0,2 & 0,5 & 0,8 & 1,7 & 2,6 & 39 \\
\hline Onderzoekend leren & 0,2 & 0,4 & 0,7 & 1,0 & 2,5 & 2,8 & 29 \\
\hline Prestatiegericht & 0,2 & 0,2 & 0,8 & 1,1 & 1,9 & 2,3 & 50 \\
\hline Samenwerken & 0,1 & 0,4 & 0,9 & 1,7 & 3,5 & 4,2 & 35 \\
\hline Sociaal-emotionele vorming & 0,1 & 0,3 & 0,7 & 1,2 & 1,7 & 4,0 & 93 \\
\hline Sportief & 0,2 & 0,4 & 0,8 & 1,4 & 2,3 & 3,6 & 116 \\
\hline Zelfstandigheid bevorderen & 0,1 & 0,2 & 0,6 & 1,2 & 2,6 & 3,7 & 36 \\
\hline
\end{tabular}

Tabel 4.4 geeft tenslotte de voorkeurscoëfficiënten weer voor de rapportcijfers en de klasgrootte. Omdat deze kenmerken als continue variabelen in de analyse zijn opgenomen, levert de analyse bij lage voorkeuren, door de betrouwbaarheidsmarges van de schattingen, soms licht negatieve waarden op, die het beste als "geen voorkeur" te interpreteren zijn. Vooral de rapportcijfers op kwaliteit, sfeer en individuele aandacht worden sterk gewaardeerd. Slechts een relatief klein deel van de ouders zou hun kind iets verder willen laten reizen voor een school waarop betrokkenheid van de ouders voorop staat. De invloed van de klassengrootte is erg klein. Er is een reductie van de klassengrootte met zo'n tien kinderen nodig om een effect te krijgen dat vergelijkbaar is met kwaliteit en sfeer.

TABEL 4.4 Verdeling bereidheid om extra te reizen naar een school per rapportcijfer en klassengrootte

\begin{tabular}{|l|r|r|r|r|r|r|}
\hline & 10e perc. & 25e perc. & 50e perc. & 75e perc. & 90e perc. & 99e perc. \\
\hline Algemene kenmerken & & & & & & \\
\hline Rapportcijfer-Kwaliteit & $-0,4$ & 0,5 & 1,7 & 3,0 & 4,3 & 6,0 \\
\hline Rapportcijfer-sfeer & $-0,7$ & 0,1 & 1,0 & 2,0 & 3,0 & 4,8 \\
\hline Rapportcijfer-individuele aandacht & $-0,7$ & 0,0 & 0,8 & 1,7 & 2,6 & 4,1 \\
\hline Rapportcijfer - betrokkenheid ouders & $-0,6$ & $-0,3$ & 0,2 & 0,7 & 1,1 & 1,9 \\
\hline Klassengrootte (per leerling erbij) & $-0,4$ & $-0,3$ & $-0,1$ & 0,1 & 0,2 & 0,5 \\
\hline N=802 & & & & & & \\
\hline
\end{tabular}

In figuur 4.2 staan de afstanden die men bereid is hun kinderen verder te laten reizen voor hun meest geprefereerde uitkomst op de attributen denominatie, aanpak en bijzondere kenmerk. Door deze attributen samen in één figuur te plaatsten kan een beeld worden gegeven van het relatief belang dat men aan deze attributen hecht in het 
algemeen, dus los van de specifieke denominatie, aanpak en bijzondere kenmerk die men het meest prefereert.

FIGUUR 4.2 Afstand die men bereid is te extra te reizen voor de meest geprefereerde uitkomst voor denominatie, aanpak en bijzondere kenmerk, t.o.v. de op-een-na meest geprefereerde uitkomst voor die attributen $(\mathrm{N}=802)$

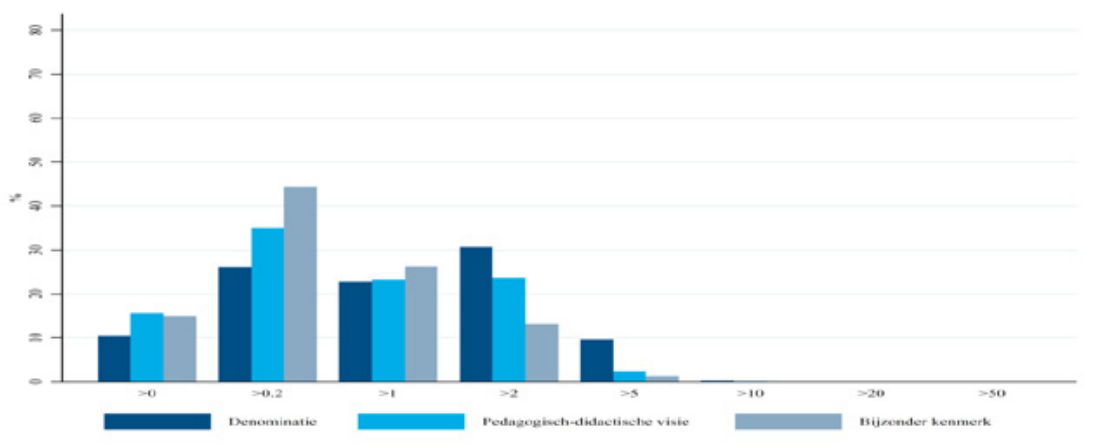

Uit deze figuur blijkt dat de bereidheid van ouders om hun kind extra te laten reizen niet heel erg verschillend is voor deze drie attributen. Ouders blijken iets vaker wat meer offers te willen brengen voor hun meest geprefereerde denominatie, en iets minder voor hun meest geprefereerde bijzonder kenmerk, maar voor alle drie attributen zijn de voorkeuren veelal verdeeld over afstanden tot ongeveer 10 kilometer. Samenvattend kan dus worden gesteld dat voor alle drie attributen er ouders zijn die er erg weinig om geven, ouders die wel om geven maar daarvoor slechts tot beperkte offers bereid zijn, en ouders die hun kinderen best veel extra kilometers per dag wil laten reizen om hun voorkeuren te realiseren. Zulke sterke voorkeuren komen duidelijk het meest voor bij denominatie, maar ook hier gaat het om een relatief klein deel van de populatie.

\section{Implicaties van verschillen in aanbod}

Doordat een groot aantal ouders meerdere basisscholen in hun directe omgeving hebben, wordt door diversiteit in het aanbod de mogelijkheid geboden om een school te selecteren die het beste bij de eigen voorkeuren past. In de praktijk is deze keuzevrijheid niet onbeperkt. Niet iedere denkbare variant kan immers in ieders nabijheid worden aangeboden. Om een beeld te geven van de mate waarin met het feitelijke aanbod aan de voorkeuren van ouders tegemoet gekomen kan worden, simuleren we de schoolkeuze van ouders bij een zo divers mogelijk aanbod.

Op basis van uitkomsten van de vignetstudie is gekeken welke school het beste aansluit bij de gemiddelde voorkeuren van de ouders. Gemiddeld over alle ouders wordt een openbare school waar ontwikkelingsgericht onderwijs wordt toegepast en waar speciale aandacht is voor de sociaal emotionele vorming het aantrekkelijkst gevonden. 
Dat zo'n school als gemiddeld het beste uit de bus komt wil niet zeggen dat dit voor veel mensen de ideale school is. Figuur 4.3 laat de verdeling zien van hoe ver men bereid is te reizen om in plaats van naar deze gemiddelde school naar de meest geprefereerde school te gaan. Voor vrijwel iedereen is er een school die aantrekkelijker is dan de school van deze gemiddelde voorkeur, en de meeste ouders zouden hun kind minstens enkele kilometers verder hiervoor willen laten reizen. De mediaan is maar liefst 7,7 kilometer.

FIGUUR 4.3 Afstand die men bereid is te extra te reizen voor de meest geprefereerde school in plaats van naar de school met gemiddeld de beste mix van attributen

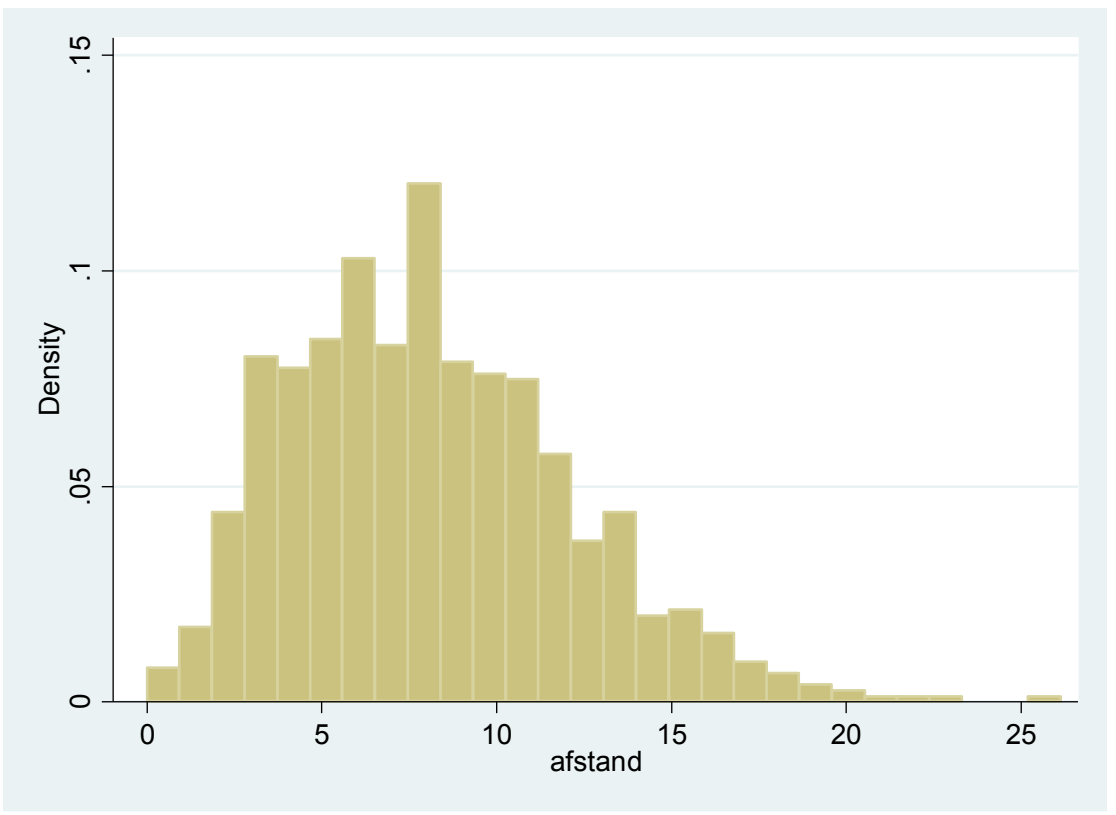

Vervolgens kijken we wat er zou gebeuren, als er één voor één steeds een school wordt toegevoegd aan het aanbod. We kiezen bij iedere stap de school die de grootste toegevoegde waarde zou hebben bij het bestaande aanbod. Figuur 4.4 laat dit zien. Door een gevarieerd aanbod vermindert de bereidheid om te reizen naar de meest geprefereerde school vrij snel. Bij vijf scholen is de mediaan nog maar 2,9 kilometer. Daarna zakt het geleidelijk naar ongeveer 1 kilometer bij een aanbod van 20 scholen. Echter zelfs bij dit veel uitgebreidere aanbod is het niet mogelijk om alle ouders tevreden te stellen. Voor $1 \%$ van de ouders is de afstand die men zou willen reizen bij een optimaal aanbod van 20 scholen toch nog 5,7 kilometer. Omdat het marginaal effect op dat punt van het toevoegen van extra scholen vrij gering is, zal de tevredenheid met het aanbod niet veel te verbeteren zijn door het verder uitbreiden van het aanbod. 
FIGUUR 4.4 Afstand die men bereid is extra te reizen voor de meest geprefereerde school bij toenemende aanbod van scholen

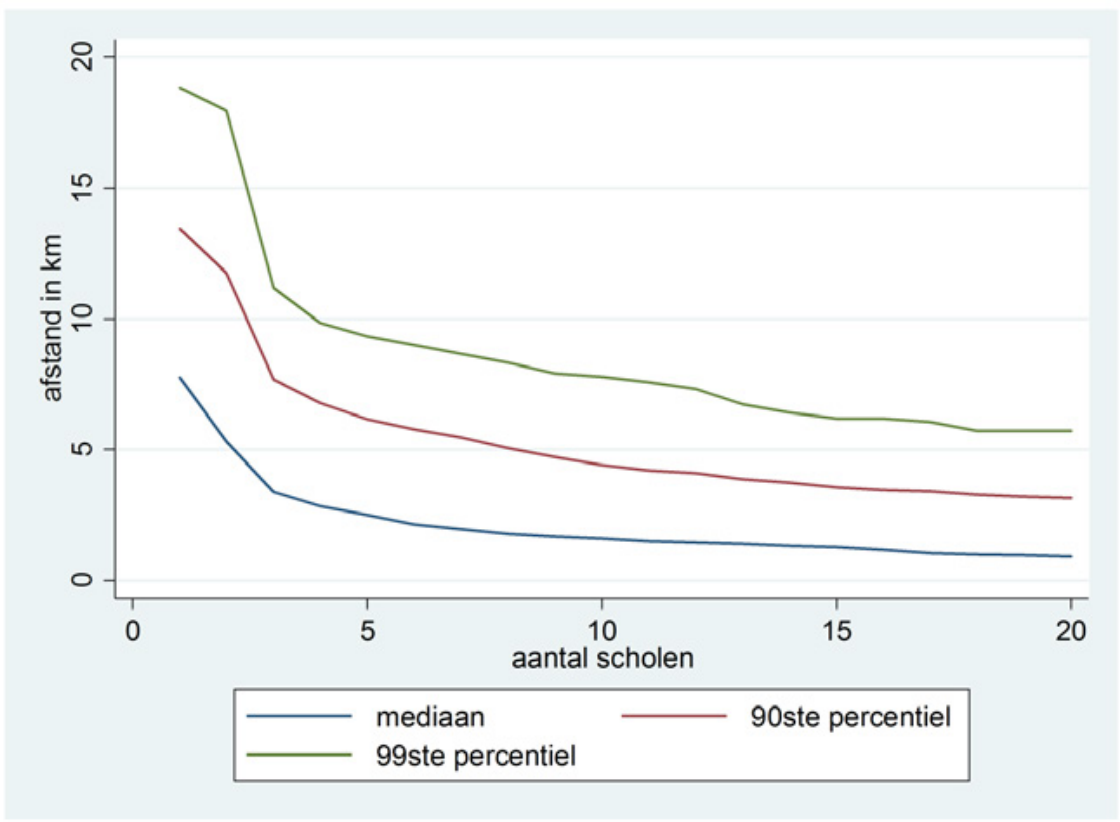

In de praktijk zal de tevredenheid met het aanbod iets groter zijn dan uit deze simulatie blijkt. In de simulatie zoeken we immers een school die past bij een representatieve steekproef van alle ouders in Nederland. Doorgaans zijn de voorkeuren van ouders in een bepaalde regio echter minder divers dan de voorkeuren van deze representatieve groep als geheel. Hierdoor zal in de praktijk minder diversiteit in aanbod nodig zijn om aan de aanwezige voorkeuren tegemoet te komen.

\section{Verdeling van voorkeuren over deelpopulaties}

Uit bovenstaande analyses is duidelijk dat er een aanzienlijke spreiding is in de voorkeuren voor de meeste attributen. Het ligt voor de hand dat deze variatie niet puur toevallig is, maar samenhangt met kenmerken van de betreffende ouders. Om iets meer reliëf te geven aan deze variatie gaan we in deze paragraaf kort in op hoe de voorkeuren voor verschillende attributen verdeeld is over bepaalde subpopulaties. We kijken naar de verdeling over de feitelijke denominatie, de regio (ingedeeld in Randstad, gemeenten met meer dan 10\% SGP stemmers in de 2012 Tweede Kamer verkiezingen; overige noorden en overige zuiden), de mate van geloof, en de opleidingsniveau van de kostwinner. Figuur 4.5 laat de verdeling van de voorkeuren voor denominatie naar deze kenmerken. 
FIGUUR 4.5 Afstand die men bereid is te extra te reizen voor de meest geprefereerde uitkomst voor denominatie, naar feitelijke denominatie, regio, mate van geloof, en opleidingsniveau van de kostwinner $(\mathrm{N}=802)$
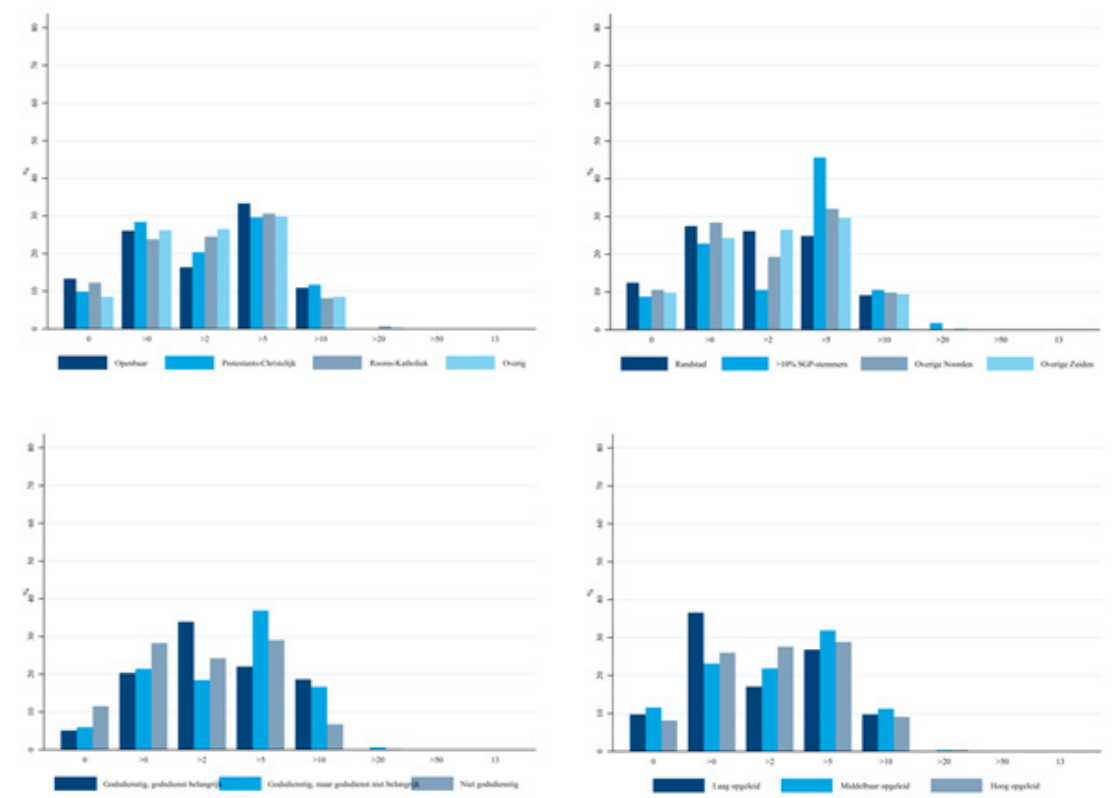

Dat de feitelijke denominatie iets anders is dan de meest geprefereerde denominatie kan worden opgemaakt uit de eerste deelgrafiek in figuur 4.5. In vergelijking tot wat in figuur 4.1 naar voren kwam, blijkt de feitelijke denominatie weinig uit te maken voor de voorkeur wanneer deze niet de meest geprefereerde denominatie is. Wat betreft regio, zien we dat vooral in delen van het land met een hoog aandeel SGP-stemmers relatief veel ouders bereid zijn hun kind verder te laten reizen voor de geprefereerde denominatie. Uit nader analyses (hier niet getoond) blijkt dat dit vooral de kleine Christelijke denominaties zijn. Verder blijkt de voorkeur voor denominatie het sterkst te zijn bij ouders die gelovig zijn. Er zijn tenslotte niet zo veel verschillen tussen ouders die qua opleidingsniveau verschillen.

Figuur 4.6 laat de verdeling over deze subpopulaties zien pedagogische-didactische aanpak. 
FIGUUR 4.6 Afstand die men bereid is te extra te reizen voor de meest geprefereerde uitkomst voor pedagogische didactische aanpak, naar feitelijke denominatie, regio, mate van geloof, en opleidingsniveau van de kostwinner ( $\mathrm{N}=802)$
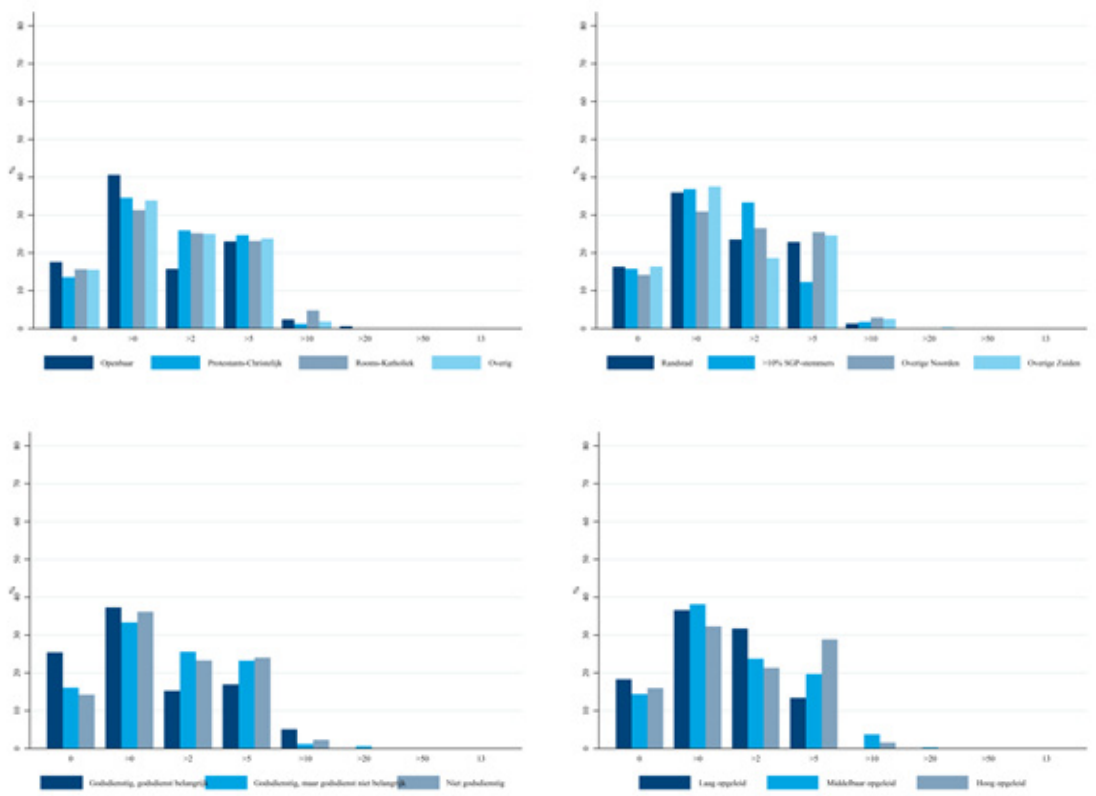

Er zijn niet zulke grote verschillen in de voorkeuren voor didactiek naar feitelijke denominatie en regio. Wel zien we dat ouders die niet gelovig zijn hun kinderen iets vaker een substantiële extra afstand zouden willen laten afleggen dan ouders die wel gelovig zijn. Ook hoogopgeleide ouders zijn iets vaker hiertoe bereid dan ouders met een middelbaar of laag opleidingsniveau.

Figuur 4.7 laat de verdeling over subpopulaties zien voor bijzondere kenmerken van de school. 
FIGUUR 4.7 Afstand die men bereid is te extra te reizen voor de meest geprefereerde uitkomst voor bijzondere kenmerk, naar feitelijke denominatie, regio, mate van geloof, en opleidingsniveau van de kostwinner $(\mathrm{N}=802)$
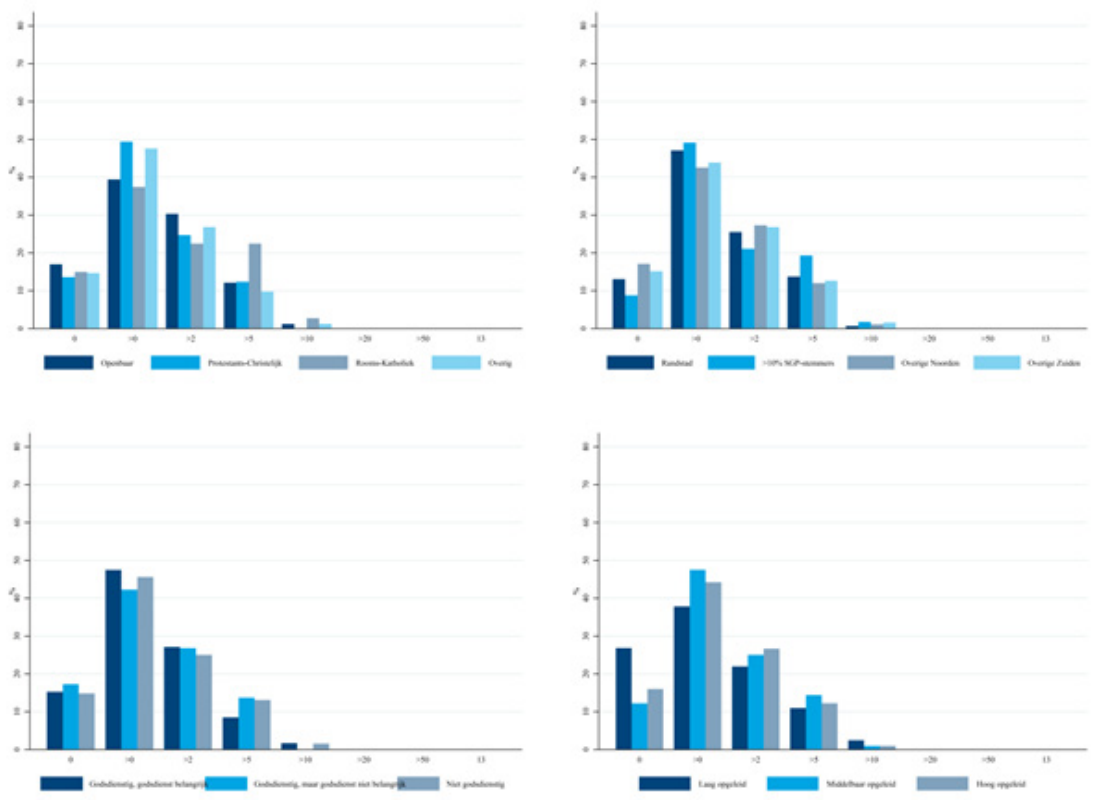

Uit deze grafieken komen geen grote verschillen naar voren.

\section{Voorkeuren van leerlingen}

Ter vergelijking kijken we ook naar de voorkeuren van leerlingen. Tabel 4.5 laat de afstanden die kinderen zelf extra zouden willen laten afleggen om hun meest geprefereerde denominatie te realiseren, relatief tot de op-een-na meest geprefereerde andere denominatie. Hieruit blijkt dat in vergelijking met ouders de kinderen meestal aanzienlijk minder ver willen reizen voor hun meest geprefereerde denominatie. Dit verschil is het grootste bij het Protestants-Christelijke onderwijs en een aantal kleine denominaties. 
TABEL 4.5 Verdeling bereidheid om extra te reizen naar een school van de meest geprefereerde denominatie in vergelijking met de op-een-na meest geprefereerde denominatie bij leerlingen $(\mathrm{N}=802)$

\begin{tabular}{|l|r|r|r|r|r|r|r|}
\hline \begin{tabular}{|r|r|r|r|r|}
$\mid$ \\
Denominatie
\end{tabular} & 10e perc. & 25e perc. & 50e perc. & 75e perc. & 90e perc. & 99e perc. \\
\hline Openbaar & 0,4 & 1,3 & 2,0 & 3,5 & 4,9 & 5,4 & 88 \\
\hline Protestants-Christelijk & 0,0 & 0,0 & 0,2 & 0,8 & 1,4 & 3,3 & 34 \\
\hline Rooms-Katholiek & 0,2 & 0,5 & 1,3 & 2,8 & 4,3 & 6,1 & 12 \\
\hline Algemeen Bijzonder & 0,4 & 1,2 & 2,4 & 4,5 & 6,8 & 10,6 & 30 \\
\hline Evangelisch & 0,2 & 0,6 & 1,0 & 2,1 & 3,2 & 4,0 & 33 \\
\hline Evangelische Broedergemeenschap & 0,1 & 0,1 & 0,4 & 1,7 & 2,1 & 2,2 & 56 \\
\hline Gereformeerd vrijgemaakt & 0,1 & 0,1 & 0,5 & 1,4 & 2,4 & 2,9 & 10 \\
\hline Reformatorisch & 0,1 & 0,3 & 1,4 & 3,2 & 6,6 & 8,4 & 28 \\
\hline Vrije School & 0,3 & 0,6 & 0,9 & 1,1 & 4,3 & 4,3 & 9 \\
\hline
\end{tabular}

In tabel 4.6 staan de afstanden die kinderen eventueel bereid zijn om te reizen voor hun meest geprefereerde pedagogisch-didactische visie. Er is over de hele linie niet heel veel verschil tussen ouders en kinderen wat betreft de voorkeuren voor dit attribuut.

TABEL 4.6 Verdeling bereidheid om extra te reizen naar een school van de meest geprefereerde visie in vergelijking met de op-een-na meest geprefereerde visie bij leerlingen $(\mathrm{N}=802)$

\begin{tabular}{|l|r|r|r|r|r|r|r|}
\hline Didactische visie & 10e perc. & 25e perc. & 50e perc. & 75 e perc. & 90 e perc. & 99 e perc. & N \\
\hline Geen & 0,6 & 1,2 & 2,7 & 4,1 & 6,0 & 10 & 113 \\
\hline Dalton & 0,3 & 0,4 & 0,8 & 1,4 & 1,7 & 1,7 & 4 \\
\hline Jenaplan & 0,4 & 0,6 & 2,2 & 2,8 & 3,6 & 4,1 & 12 \\
\hline Montessori & 0,0 & 0,0 & 0,6 & 2,1 & 4,3 & 4,3 & 8 \\
\hline Ervaringsgericht onderwijs & 0,5 & 0,8 & 0,9 & 1,5 & 1,9 & 1,9 & 5 \\
\hline Kees Boeke & 0,2 & 0,4 & 1,3 & 2,3 & 3,7 & 5,2 & 28 \\
\hline Nieuw leren/natuurlijk leren & 0,2 & 0,3 & 1,1 & 1,8 & 2,0 & 3,3 & 16 \\
\hline Steve JobsSchool & 0,3 & 0,5 & 0,9 & 1,8 & 3,8 & 5,6 & 114 \\
\hline
\end{tabular}

Tabel 4.7 toont de bereidheid van kinderen om verder te reizen voor hun meest geliefde bijzondere kenmerken. Ook hier blijken de kinderen op de meeste punten niet veel te verschillen van de ouders. Wel lijken kinderen meer over te hebben voor scholen waar bepaalde kenmerken voorop staan, zoals creativiteit en ICT. 
TABEL 4.7 Verdeling bereidheid om extra te reizen naar een school van de meest geprefereerde bijzonder kenmerk in vergelijking met de op-een-na meest geprefereerde bijzonder kenmerk bij leerlingen $(\mathrm{N}=802)$

\begin{tabular}{|c|c|c|c|c|c|c|c|}
\hline & 10e perc. & 25e perc. & 50 e perc. & 75e perc. & 90 e perc. & 99e perc. & N \\
\hline \multicolumn{8}{|l|}{ Bijzondere kenmerken } \\
\hline Creatief & 0,2 & 0,8 & 1,9 & 3,4 & 5,6 & 9,1 & 80 \\
\hline Geloof centraal & 1,5 & 1,5 & 2,2 & 3,6 & 3,6 & 3,6 & 3 \\
\hline Gepersonaliseerd leren & 0,2 & 0,7 & 1,1 & 1,3 & 1,9 & 2,3 & 14 \\
\hline Kunstzinnig & 0,3 & 0,3 & 0,3 & 0,3 & 0,3 & 0,3 & 1 \\
\hline Leren door spelen & 0,1 & 0,2 & 0,4 & 0,7 & 1,0 & 1,2 & 10 \\
\hline Leren met ICT & 0,2 & 0,7 & 1,3 & 2,3 & 3,8 & 6,4 & 68 \\
\hline Muzikaal onderwijs & 0,1 & 0,2 & 0,9 & 2,6 & 3,1 & 3,9 & 11 \\
\hline Onderzoekend leren & 0,2 & 0,3 & 0,6 & 1,1 & 1,6 & 4,5 & 21 \\
\hline Prestatiegericht & 0,6 & 0,9 & 1,7 & 2,4 & 2,8 & 4,8 & 21 \\
\hline Samenwerken & 0,0 & 0,4 & 0,8 & 1,9 & 2,4 & 3,1 & 28 \\
\hline Sociaal-emotionele vorming & 0,0 & 0,5 & 0,9 & 1,4 & 3,2 & 3,2 & 6 \\
\hline Sportief & 0,3 & 0,5 & 0,9 & 1,4 & 1,9 & 4,3 & 22 \\
\hline Zelfstandigheid bevorderen & 0,1 & 0,1 & 0,9 & 1,7 & 2,5 & 2,5 & 15 \\
\hline
\end{tabular}

Tabel 4.8 tenslotte laat de waardering voor kinderen voor andere aspecten: kwaliteit, sfeer, individuele aandacht, betrokkenheid van ouders en klasgrootte. In zowel relatieve als absolute zin waarderen ze deze op een vergelijkbare wijze als ouders, waarbij vooral de eerste drie attributen op waardering kunnen rekenen.

TABEL 4.8 Verdeling bereidheid om extra te reizen naar een school per rapportcijfer en klassengrootte bij leerlingen $(\mathrm{N}=8 \mathrm{O} 2)$

\begin{tabular}{|l|r|r|r|r|r|r|}
\hline Bijzondere kenmerken & 10e perc. & 25e perc. & 50e perc. & 75e perc. & 90e perc. & 99 e perc. \\
\hline Rapportcijfer - $k$ waliteit & $-0,9$ & 0,5 & 1,6 & 3,2 & 4,2 & 5,9 \\
\hline Rapportcijfer - sfeer & $-0,2$ & 0,4 & 1,3 & 2,3 & 3,1 & 4,2 \\
\hline Rapportcijfer - individuele aandacht & $-1,2$ & $-0,1$ & 1,0 & 2,0 & 2,7 & 4,3 \\
\hline Rapportcijfer - betrokkenheid ouders & $-0,1$ & 0,2 & 0,6 & 0,9 & 1,2 & 1,6 \\
\hline Klasgrootte (per leerling erbij) & $-0,5$ & $-0,2$ & $-0,1$ & 0,1 & 0,3 & 0,6 \\
\hline N=300 & & & & & & \\
\hline
\end{tabular}





\section{5 \\ ANALYSE VAN POPULATIEDATA VAN LEERLINGEN}

In deze paragraaf presenteren we de resultaten van analyses van micro-data van de gehele populatie leerlingen zoals in de door DUO beheerde scholenbestanden. We zijn dus nu terug bij de feitelijk schoolkeuzes van leerlingen. We hebben per leerling de afstand berekend naar de school waarop die zit, evenals naar andere scholen in dezelfde buurt of regio. De redenering achter deze analyses is dat de gereisde afstand boven wat strikt nodig is iets zegt over voorkeuren, en van het aanbod van scholen die aan deze voorkeuren voldoen. Deze "meerafstand" wordt namelijk deels bepaald door de voorkeuren van ouders en kinderen voor scholen van het gewenst profiel, en deels door het aanbod van scholen die aan hun voorkeuren voldoen. We hebben ook een maat ontwikkeld voor het kwantitatieve aanbod in de regio: het aantal scholen binnen een straal van 5 kilometer rondom het ouderlijk huis.

Figuur 5.1 toont de verdeling van de gemiddelde afstand naar de dichtstbijzijnde school, en de gemiddelde extra afstand die men hier bovenop aflegt om dagelijks naar school te gaan. Hieruit blijkt dat er voor de meeste mensen minstens één school is binnen 1 kilometer van het ouderlijk huis. Voor zo'n $22 \%$ van de leerlingen is er zelfs een school binnen 200 meter van huis. Zo'n $60 \%$ van de leerlingen reist niet of nauwelijks verder dan strikt nodig is om naar school te gaan, ${ }^{1}$ en nog eens een kwart legt tot 1 kilometer meer af ten opzichte van de dichtstbijzijnde school. Zo'n 2\% legt meer dan 5 kilometer meer af dan strikt nodig, en dit loopt incidenteel op naar meer dan 50 kilometer.

1 Zo'n 45\% kiest letterlijk de dichtsbijzijnde school, en 15\% een school die maximaal 200 meter verder van huis ligt dan de dichtstbijzijnde school. 
FIGUUR 5.1 Gemiddelde afstand naar de dichtstbijzijnde basisschool en extra afstand gereisd t.o.v. dichtstbijzijnde basisschool, 2015

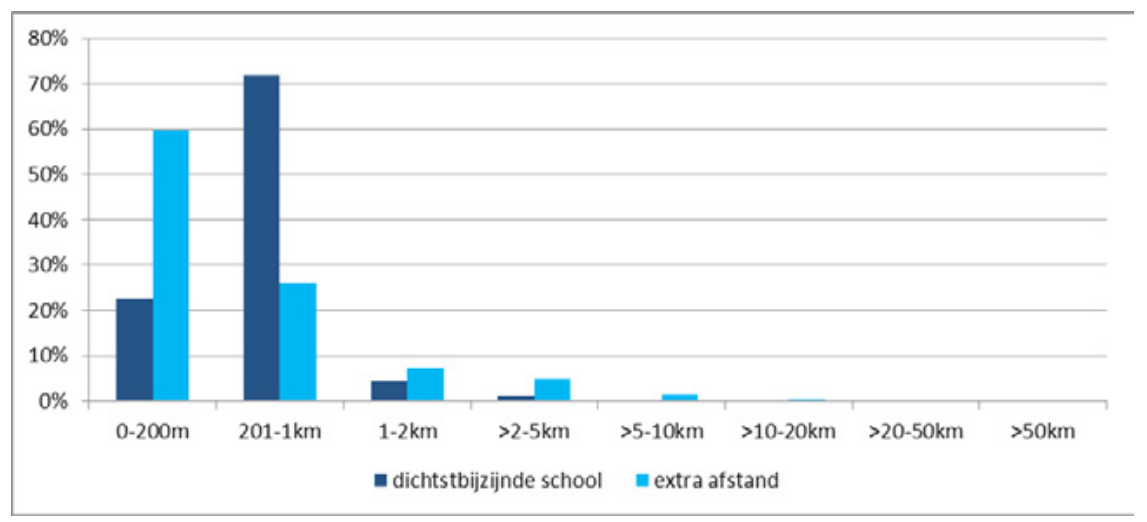

Figuur 5.2 toont het gemiddeld aantal basisscholen binnen een straal van 5 kilometer van het ouderlijk huis. Hieruit blijkt dat er grote verschillen zijn in termen van het kwantitatieve aanbod waarmee mensen te maken hebben. Voor zo'n $8 \%$ van de leerlingen is binnen een straal van 5 kilometer van het ouderlijk huis een school te vinden. Dit komt overheen met minder dan één school per $4 \mathrm{~km}^{2}$. Aan het andere uiterste zijn voor zo'n $9 \%$ van de mensen meer dan 200 scholen binnen eenzelfde straal, wat overeenkomt met meer dan 2,5 scholen per vierkante kilometer. De meeste mensen hebben te maken met een aanbod tot ongeveer 100 scholen binnen 5 kilometer van hun ouderlijk huis. Naar verwachting zal door de leerlingendaling dit aanbod iets minder worden in de komende jaren.

\section{FIGUUR 5.2 Gemiddeld aantal basisscholen binnen $5 \mathrm{~km}$ van het ouderlijk huis, 2015}

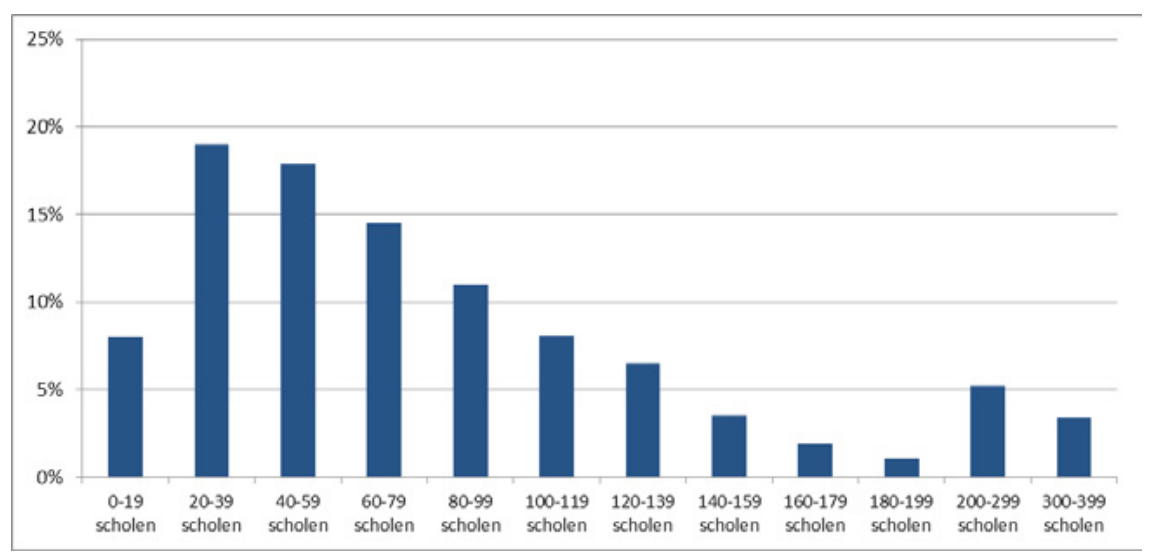

Het laat zich raden dat deze cijfers een sterke regionale differentie zullen tonen. Figuur 5.3 toont het gemiddelde afstand naar de dichtstbijzijnde basisschool per gemeente in 
Nederland. Omdat sommige gemeenten relatief weinig leerlingen kennen is gebruik gemaakt van gepoolde data over de recentste drie jaren waarover we data hebben, namelijk 2013-2015. Uit deze figuur komt het verwachte beeld naar voren: lage gemiddelde afstanden in en om de randstad, toenemend naarmate de gemeente daar verder van afligt. Vooral in het noorden lijken er veel gemeenten te zijn met een relatief hoog gemiddelde afstand naar de dichtstbijzijnde school.

FIGUUR 5.3 Gemiddelde afstand naar de dichtstbijzijnde basisschool, per gemeente, gepoolde data 2013-2015

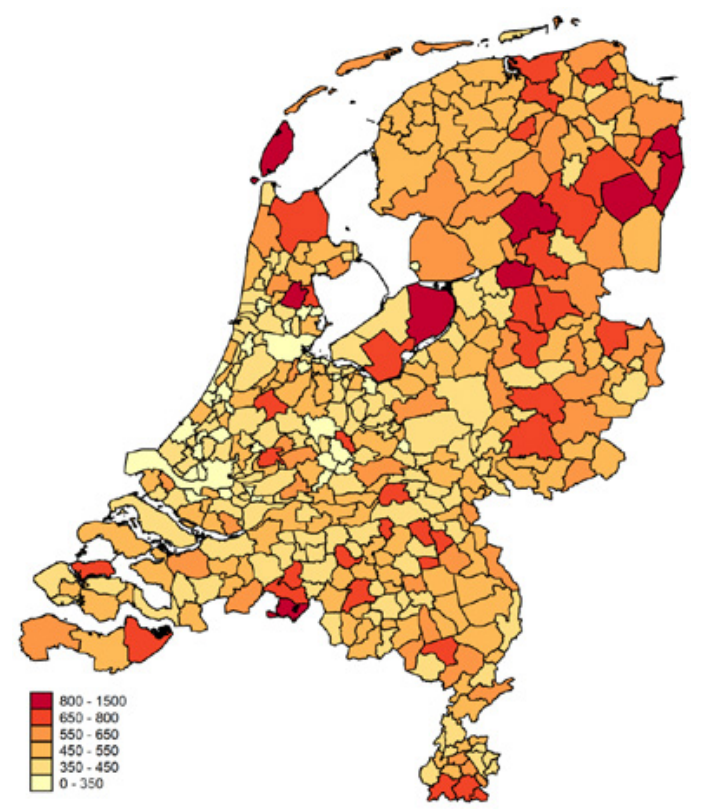

Figuur 5.4 laat het gemiddeld aantal scholen binnen een straal van 5 kilometer van het thuisadres zien. Het patroon komt vrij sterk overeen met dat van de afstand naar de dichtstbijzijnde school, maar is niet identiek. Dit heeft te maken met het spreidingspatroon van leerlingen in een gemeente, en dat van scholen in dezelfde of nabijgelegen gemeenten waar deze kinderen potentieel naartoe zouden kunnen gaan. Figuur 5.5 illustreert dit verschil. In deze figuur wordt een gemeente met relatief weinig scholen binnen een straal van $5 \mathrm{~km}$, maar die zo geplaatst zijn dat de meest inwoners niet ver van huis hoeven te reizen om een basisschool te vinden (links), gecontrasteerd met een gemeente waar het omgekeerde het geval is (rechts). 
FIGUUR 5.4 Gemiddeld aantal basisscholen binnen $5 \mathrm{~km}$ van het ouderlijk huis, per gemeente, gepoolde data 2013-2015

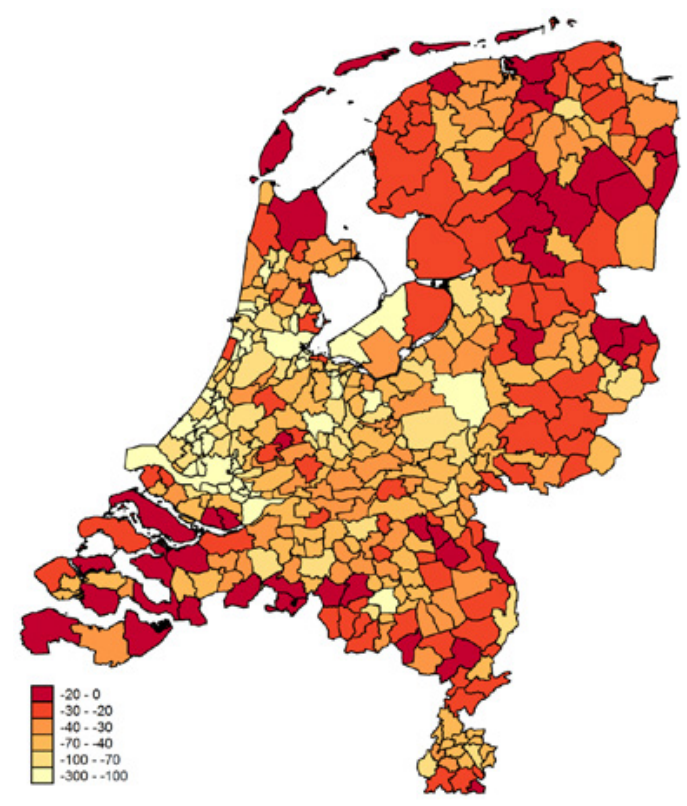

FIGUUR 5.5 Verdeling van basisschoolleerlingen en basisscholen in twee verschillende gemeenten, 2015

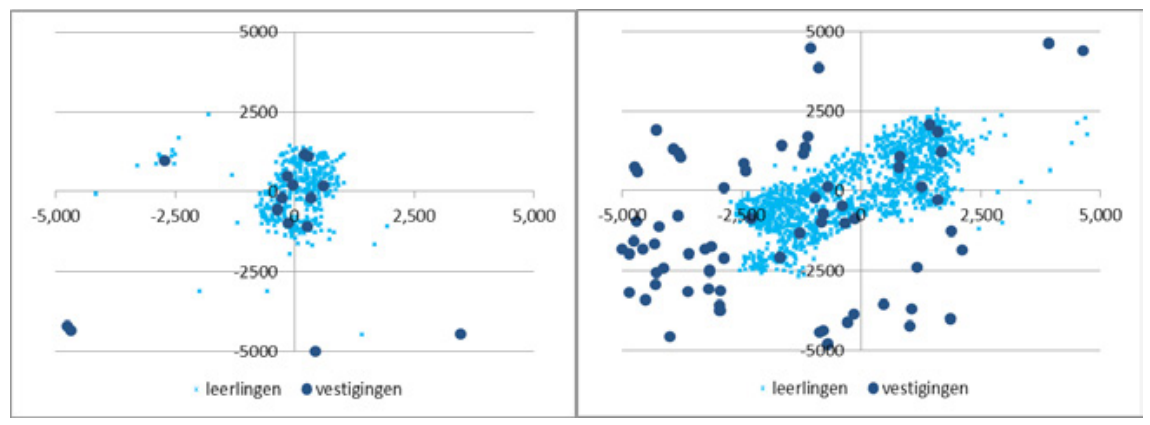

Figuur 5.6 toont de gemiddelde afstand die men verder naar school reist dan strikt nodig is. Een opvallende regionale verdeling komt hieruit naar voren, waarbij men grof gezegd beneden de grote rivieren (met uitzondering van Zuid Limburg) weinig geneigd is om verder te reizen dan strikt nodig is, terwijl rondom en boven de grote rivieren men daartoe veel meer geneigd lijkt te zijn. 
FIGUUR 5.6 Gemiddelde extra afstand gereisd t.o.v. de dichtstbijzijnde basisschool, per gemeente, gepoolde data 2013-2015

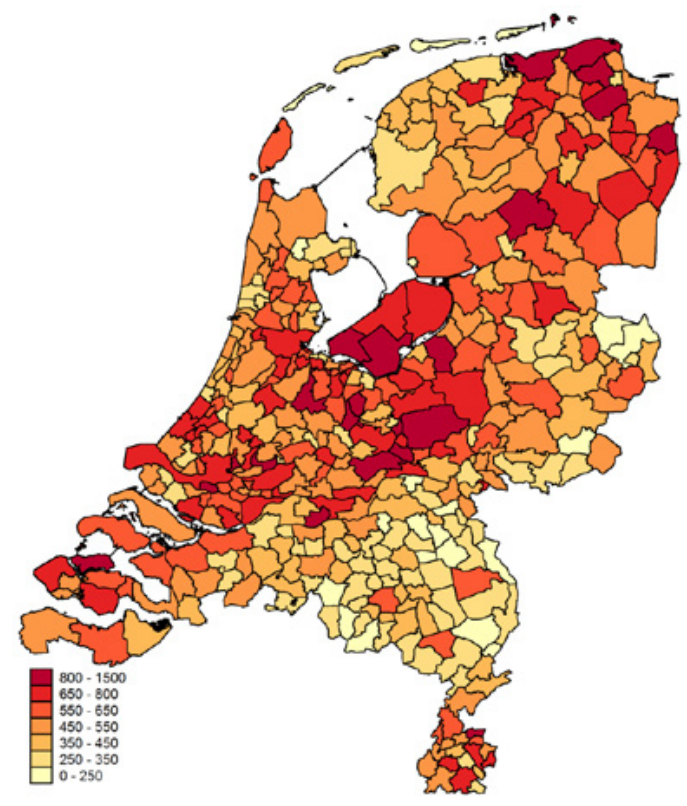

Het kan zijn dat er meerdere krachten in het spel zijn hier. Vooral in de noordelijke gemeenten zou het kunnen zijn dat het geringe aanbod dwingt tot het afleggen van grotere afstanden. In de randstad zou tot op zekere hoogte een omgekeerd effect kunnen zijn, namelijk dat door het grote aanbod er vrijwel altijd een school in de buurt is die qua profiel zeer goed aan de wensen en de voorkeuren van de ouders en kinderen voldoet, hetzij niet altijd pal naast de deur. Door dit gevarieerde aanbod loont het de moeite om iets verder te gaan dan men zou doen wanneer er veel minder keuze zou zijn. In het gebied rondom de grote rivieren tenslotte wonen relatief veel mensen met een Christelijke levensovertuiging, en van deze groepen is bekend dat ze veel waarde hechten aan het vinden van een school voor hun kinderen waar dat geloof wordt uitgedragen. Een vergelijking tussen figuur 5.6 en figuur 5.7, waarin het aandeel leerlingen per gemeente dat op een school zit met de denominatie Reformatorisch, Gereformeerd Vrijgemaakt, Evangelisch of Evangelische Broedergemeente staat afgedrukt, maakt duidelijk hoe sterk deze geloofsovertuiging doorwerkt in de bereidheid verder te reizen voor een passende school. 
FIGUUR 5.7 Aandeel leerlingen op Reformatorisch, Gereformeerd Vrijgemaakt, Evangelisch of Evangelische Broedergemeente scholen, per gemeente, gepoolde data 2010-2015

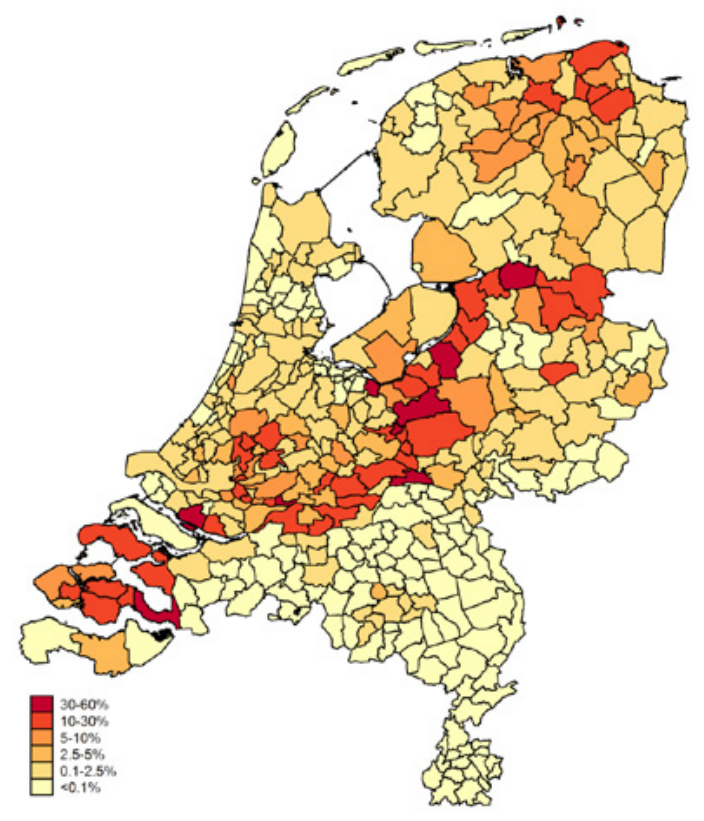

In de volgende figuren wordt gekeken hoe stabiel dan wel veranderlijk deze indicatoren zijn in de tijd. Uit figuren 5.8 en 5.9 blijkt dat het aanbod en bijbehorend afstand tot de dichtstbijzijnde school nauwelijks veranderd is in de afgelopen zes jaren. Figuur 5.8 daarentegen laat een ontwikkeling zien in de extra afstanden die worden afgelegd ten opzichte van de dichtstbijzijnde school. Dit is het sterkst te zien bij de hoogste percentielen, maar dat komt door de gebruikte schaal. In alle percentielgroepen zijn de afstanden toegenomen. Interessant genoeg springt het $50^{\mathrm{e}}$ percentiel (anders gezegd: de mediaan) wat dat betreft uit. In deze percentielgroep is de extra afstand sinds 2010 van bijna 40 meter naar bijna 60 meter gestegen, een stijging van 50\%. Bij hogere en lagere percentielen is de stijging zo'n $15 \%$ in dezelfde periode. Het is onduidelijk wat aan dit patroon ten grondslag ligt. 
FIGUUR 5.8 Afstand naar de dichtstbijzijnde basisschool, $10^{\mathrm{e}}, 30^{\mathrm{e}}, 50^{\mathrm{e}}, 70^{\mathrm{e}}, 90^{\mathrm{e}}$ en $99^{\mathrm{e}}$ percentiel, trend 2010-2015

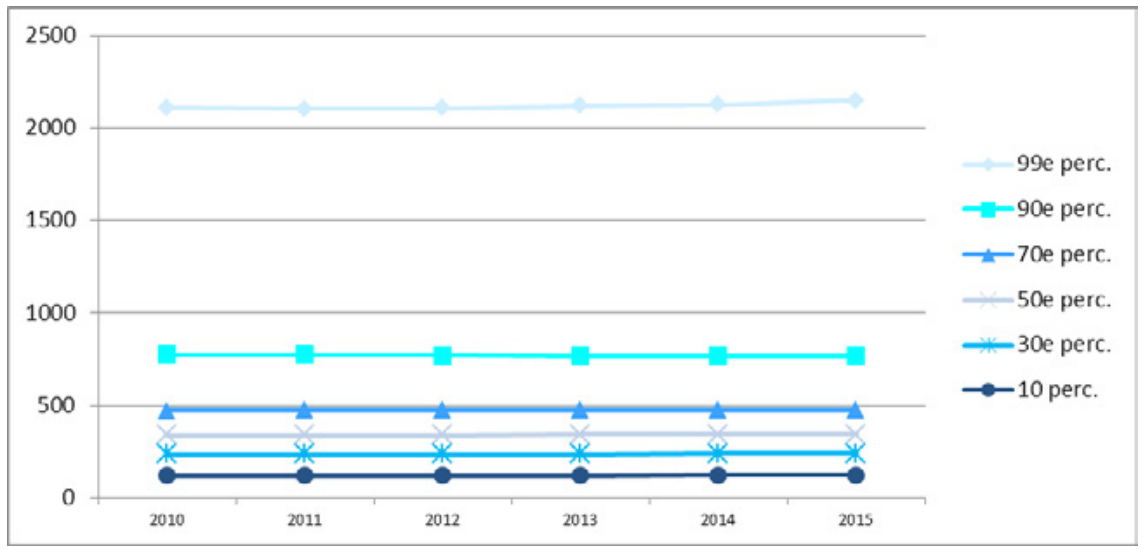

FIGUUR 5.9 Aantal basisscholen binnen $5 \mathrm{~km}$ van het ouderlijk huis, $10^{\mathrm{e}}, 30^{\mathrm{e}}, 50^{\mathrm{e}}, 70^{\mathrm{e}}, 90^{\mathrm{e}}$ en $99^{\mathrm{e}}$ percentiel, trend 2010-2015

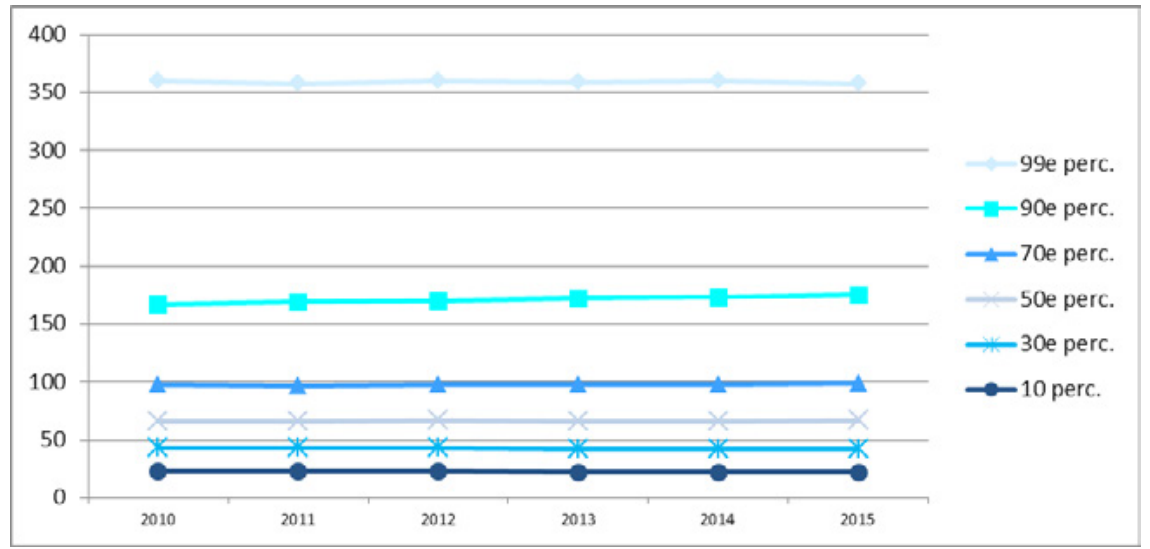


FIGUUR 5.10 Extra afstand gereisd t.o.v. de dichtstbijzijnde basisschool, $10^{\mathrm{e}}, 30^{\mathrm{e}}, 50^{\mathrm{e}}, 70^{\mathrm{e}}, 90^{\mathrm{e}}$ en $99^{\mathrm{e}}$ percentiel, trend 2010-2015

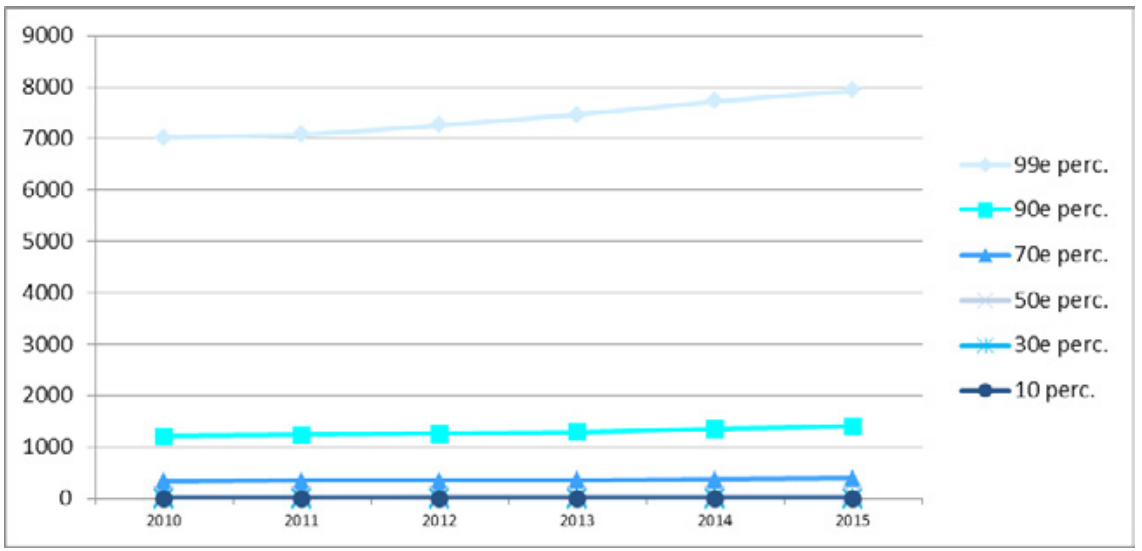

Figuren $5.11 \mathrm{t} / \mathrm{m} 5.13$ tonen deze indicatoren naar denominatie van de eigen school. Uit figuur 5.11 komt naar voren dat er weinig verschil is tussen de denominaties voor wat betreft de afstand tot de dichtstbijzijnde school. Let wel: dit hoeft niet een school te zijn in de betreffende denominatie. Kinderen op Rooms-Katholieke scholen hebben iets minder vaak een (ander) school dicht in de buurt, en iets vaker een school die tot 2 kilometer van huis is verwijderd. Uit figuur 5.12 komt naar voren dat ze ook relatief vaak in een buurt woonden met een relatief laag kwantitatief aanbod.

FIGUUR 5.11 Gemiddelde afstand naar de dichtstbijzijnde basisschool en extra afstand gereisd t.o.v. dichtstbijzijnde basisschool, naar denominatie eigen school, 2015

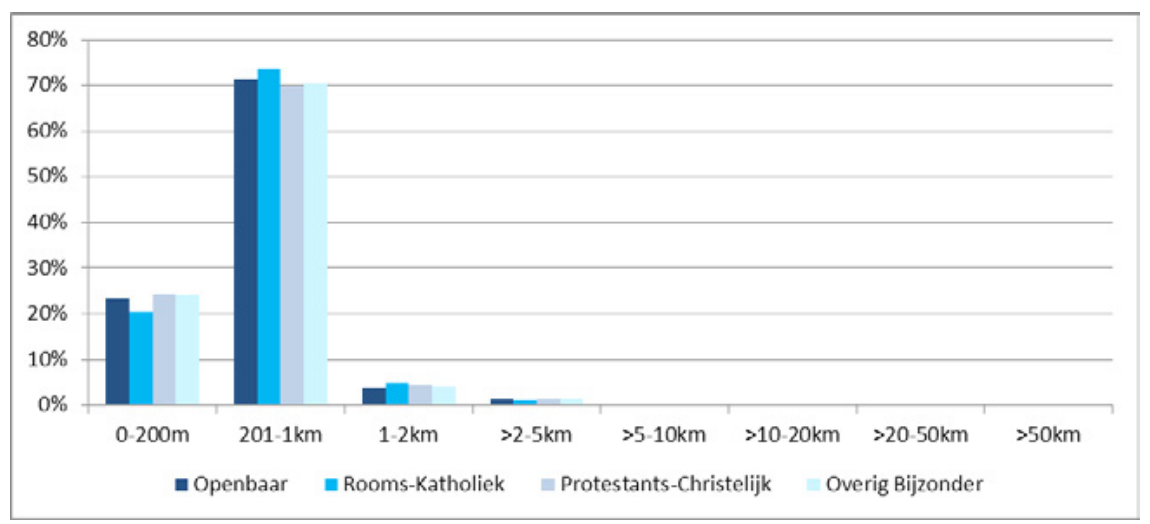


FIGUUR 5.12 Gemiddeld aantal basisscholen binnen $5 \mathrm{~km}$ van het ouderlijk huis, naar denominatie, 2015

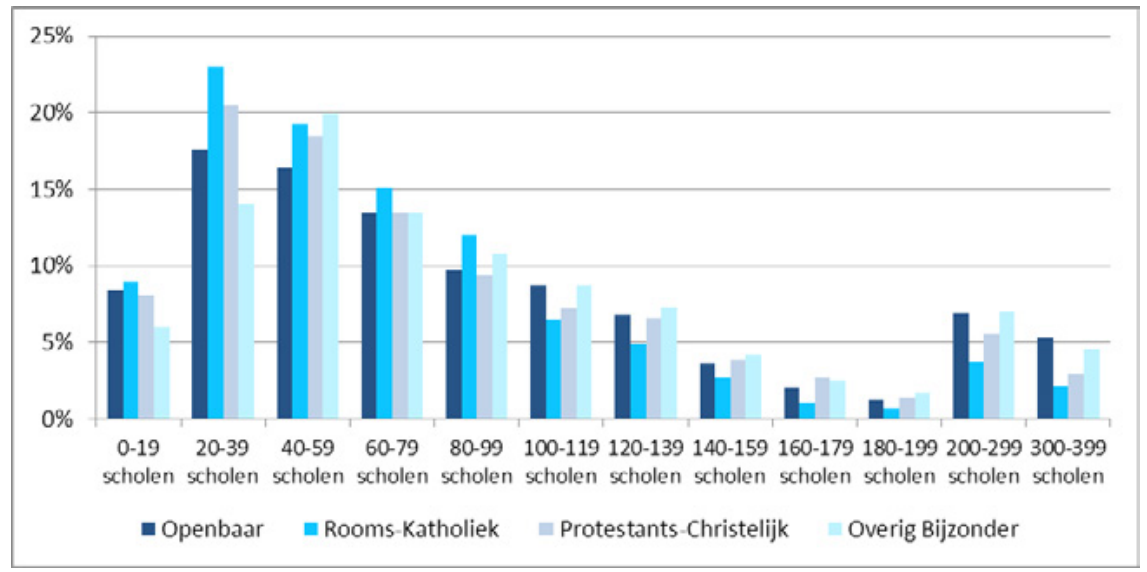

Figuur 5.13 laat zien dat kinderen op Overige Bijzondere scholen minder vaak op een school zitten die (nagenoeg) het dichtst bij huis ligt. In alle overige categorieën worden deze scholen juist oververtegenwoordigd. Dit is consistent met het beeld dat in paragraaf 4 en 5 naar voren kwam.

FIGUUR 5.13 Extra afstand gereisd t.o.v. de dichtstbijzijnde basisschool, naar denominatie eigen school, 2015

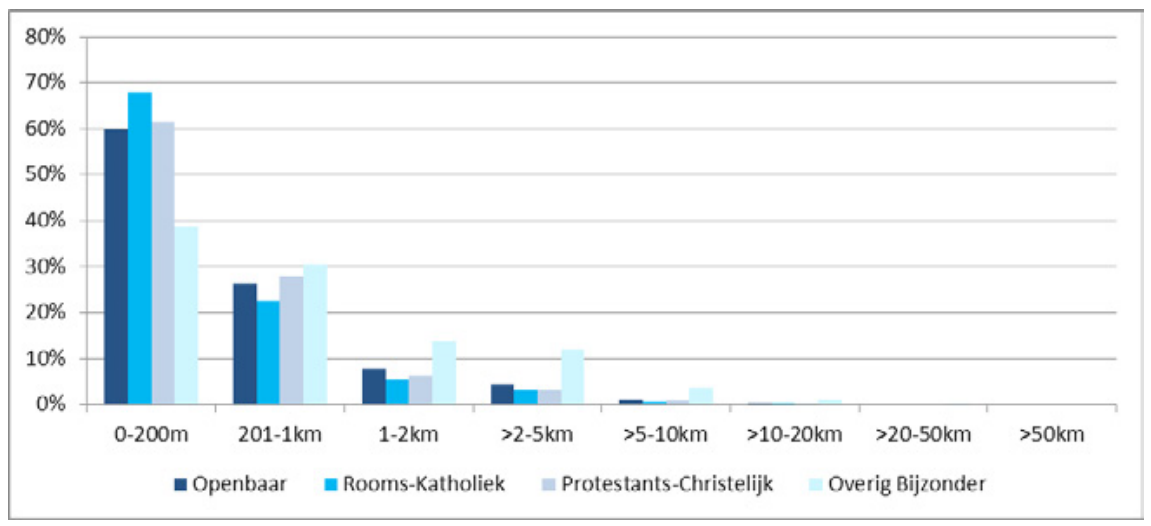

Nadere analyses (niet getoond) laten zien dat er geen grote verschillen zijn naar geslacht en etniciteit van leerlingen in de bereidheid extra te reizen ten opzichte van de dichtstbijzijnde school. Autochtone leerlingen kiezen iets vaker dan westerse- en niet-westerse allochtonen voor de dichtstbijzijnde school of een andere school op vergelijkbare afstand van thuis. Dit lijkt te maken te hebben met het feit dat autochtonen vaker in 
plattelandsgemeenten wonen met een geringer scholenaanbod. Door het gebrek aan andere opties kiezen deze leerlingen meestal de enige dorpsschool, omdat ze anders veel verder zullen moeten reizen naar een alternatieve school. Allochtonen daarentegen zijn sterk geconcentreerd in de grote steden, waar het de moeite loont om wat verder te gaan, om zodoende een school van het gewenste profiel te krijgen.

Deze relatie tussen extra afgelegde afstand en het kwantitatieve scholenaanbod wordt getoond in figuur 5.14. In buurten waar er weinig scholen liggen worden langere afstanden afgelegd bovenop wat strikt nodig zou zijn, maar alleen voor de hoogste percentielen. Voor de overige percentielen neemt de afstand juist toe met het aanbod. Dit laatste effect ligt aan de basis van de langere extra afstanden die in de randstad worden afgelegd (zie figuur 5.6), en dus ook voor de grote groepen allochtonen die daar wonen. Meer scholen betekent meer keuze, en meer keuze maakt dat het meer de moeite waard is om te zoeken naar geschikte scholen. Aan het andere uiterste, wanneer er erg weinig scholen in de buurt zijn, betekent het overslaan van de dichtstbijzijnde school al gauw een lange "meerafstand". Voor de meest mensen is zo'n offer niet de moeite waard, dus kiezen ze toch de dichtstbijzijnde school. Voor een minderheid is echter de dichtstbijzijnde school toch totaal onacceptabel. Deze mensen hebben het er dus voor over om hun kinderen veel verder naar school te laten reizen.

FIGUUR 5.14 Extra afstand gereisd t.o.v. de dichtstbijzijnde basisschool, naar aantal scholen binnen $5 \mathrm{~km}, 2015$

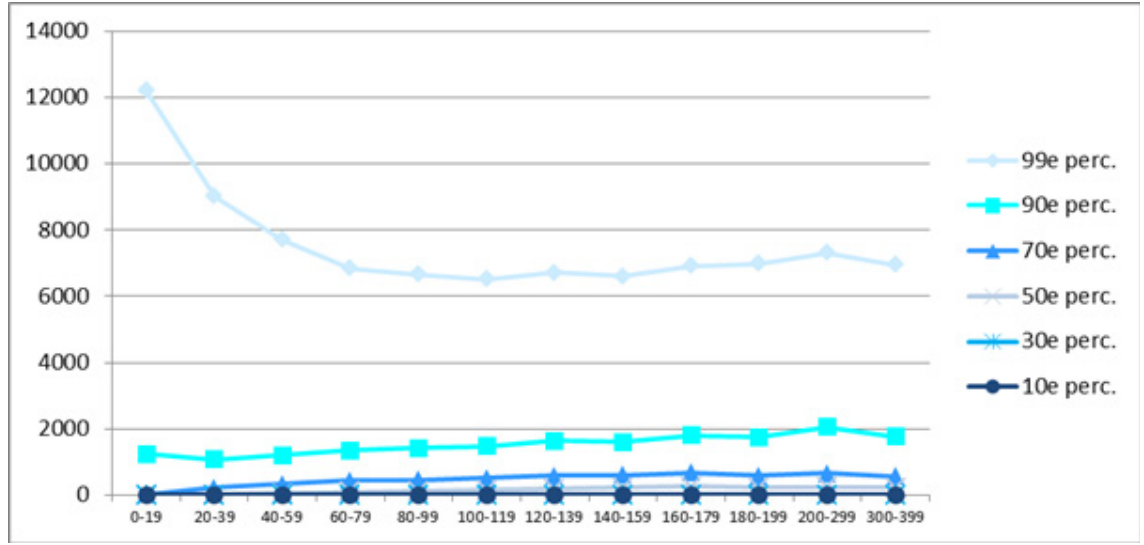




\section{6 \\ CONCLUSIES}

\section{Recapitulatie hoofdvragen}

In dit rapport hebben we verslag uitgebracht van een uitgebreid onderzoek over schoolkeuzemotieven van ouders en leerlingen in het primair onderwijs. De overkoepelende onderzoeksvraag hierbij luidde: Wat zijn de belangrijkste motieven en behoeften van ouders en leerlingen bij het kiezen van een nieuwe dan wel bestaande school in het primair onderwijs? Hoe groot is de diversiteit in deze voorkeuren en in hoeverre voorziet het bestaande aanbod in deze behoefte? Om deze vragen te onderzoeken hebben we drie uitgebreide deelanalyses verricht. In een eerste analyse hebben we gekeken naar de afstanden die ouders aangaven bereid te zijn om hun kind extra te laten reizen voor hun meest geprefereerde denominatie. In een tweede analyse hebben we een vignettenmethodologie gebruikt om voorkeuren van ouders en leerlingen over een bredere scala aan attributen bloot te leggen. In de derde en laatste grote analyse hebben we gebruik gemaakt van de door DUO beheerde leerlingenbestanden om feitelijke schoolkeuzes van ouders en leerlingen te analyseren. Omdat voorkeuren niet absoluut zijn, maar altijd een bepaalde afweging inhouden met andere kenmerken, ontstond een behoefte aan een gemeenschappelijk schaal waarop voorkeuren voor uiteenlopende attributen van scholen kon worden gemeten. In dit rapport hebben we afstand als meetlat gehanteerd. Dit heeft ons in staat gesteld om de voorkeuren voor denominaties, pedagogischedidactische aanpakken, schoolkwaliteit en andere bijzondere kenmerken van scholen direct met elkaar te vergelijken. Omdat afstand als meetlat fungeerde in alle drie deelonderzoeken, was ook mogelijk de resultaten van deze deelstudies direct met elkaar te vergelijken.

\section{Motieven van ouders en leerlingen bij schoolkeuze}

In dit onderzoek zijn verschillende motieven die aan schoolkeuzes ten grondslag kunnen liggen onderzocht. Bij de analyses werd vooral ingegaan op voorkeuren die gebaseerd zijn op denominatie, pedagogisch-didactisch concept en bijzondere profileringskenmerken, zoals aandacht voor gepersonaliseerd leren, aandacht voor sociaal-emotionele vorming, enzovoorts. Dit zijn kenmerken waarop scholen zich sterk kunnen profileren, en waarop ouders en kinderen zouden kunnen letten wanneer ze op zoek zijn naar een school met een uitgesproken profiel die bij hun voorkeuren past. Verder worden voorkeuren gemeten voor een aantal attributen, waaronder de afstand van thuis naar school. Door de voorkeuren van andere attributen hieraan te relateren, konden deze 
voorkeuren worden uitgedrukt in termen van de afstand die men bereid is om hiervoor te reizen.

Vrijwel alle ouders hebben een voorkeur voor een bepaalde denominatie, pedagogischdidactische visie of bijzondere kenmerk en zijn bereid hiervoor (hun kind) verder te (laten) reizen. Denominatie is een belangrijk motief voor ouders bij de schoolkeuze, maar bijzondere kenmerken en pedagogische aanpak zijn in vergelijkbare mate ook belangrijk. Voor alle drie schoolattributen zijn er veel ouders die bereid zijn om hun kinderen desnoods een substantieel extra afstand te laten reizen om hun meest geprefereerde uitkomst te realiseren. Dit geldt ook voor de kinderen zelf.

\section{Diversiteit in voorkeuren van ouders en leerlingen}

Het is niet zo dat alle ouders en kinderen even sterke voorkeuren hebben voor denominatie, aanpak en bijzondere kenmerken. $10 \%$ van de ouders is helemaal niet bereid hun kinderen te laten reizen om hun meest geprefereerde denominatie te realiseren, en nog eens een kwart wil hun kinderen maximaal 1 kilometer verder laten reizen. Aan het andere uiterste zijn er ouders die bereid zijn om hun kinderen desnoods tientallen kilometers verder te laten reizen om naar een school te kunnen gaan die aan hun wensen voldoet. Zulke extremen zijn vrij uitzonderlijk, maar na controle voor andere voorkeuren wil 10\% van de ouders hun kind desnoods meer dan 5 kilometer verder laten reizen dan strikt nodig is. Ook de sterkte van voorkeuren voor aanpak en bijzondere kenmerken varieert aanzienlijk tussen ouders en kinderen. Bij deze attributen wil zo'n 15\% van de ouders hun kinderen helemaal niet verder laten reizen, en is ongeveer $3 \%$ bereid hun kinderen desnoods meer dan 5 kilometer verder te laten reizen.

De voorkeuren verschillen ook naar regio, geloof en opleidingsniveau van de ouders. We zien een sterkere voorkeur voor denominatie in delen van het land met veel SGP stemmers, dat weerspiegeld wordt in de feitelijk gereisde afstanden die uit de analyses van de door DUO beheerde landelijke registerdata naar voren komt, en ook door de sterkere voorkeuren voor denominatie onder gelovige ouders. Uit de registerdata komt tevens naar voren dat leerlingen in de randstad en de noordelijke provincies relatief vaak relatief lange afstanden afleggen om naar school te gaan, boven wat strikt nodig is. Deze effecten lijken te worden gedreven door veel keuze in het eerste geval (veel aanbod in de buurt, maar niet per se naast de deur), en door weinig keuze in het tweede geval (een lage scholendichtheid, gecombineerd met relatief sterke voorkeuren). Opleidingsniveau lijkt vooral een effect te hebben op de voorkeuren voor pedagogisch-didactische aanpak en bijzondere kenmerken. Hoogopgeleide ouders hebben vaker een sterke voorkeur voor aanpak, en laagopgeleide ouders willen relatief vaak hun kinderen helemaal niet verder laten reizen voor hun meest geprefereerde bijzonder kenmerk.

De voorkeuren van kinderen weerspiegelen vaak die van ouders, maar er zijn verschillen. Zo willen kinderen meestal aanzienlijk minder ver reizen voor hun meest geprefereerde denominatie. Wat aanpak betreft lijken de voorkeuren van ouders en kinderen meer op elkaar, waarbij de sterkere waardering door ouders alleen voor bepaalde aanpakken 
geldt. Ook de voorkeur voor bijzondere kenmerken lijkt niet veel te verschillen tussen ouders en kinderen. Voor een aantal kenmerken tonen kinderen zich zelfs tot grotere reisafstand bereid dan door ouders wordt verlangd.

\section{Toereikendheid bestaand aanbod}

Uit de analyses komt dus naar voren dat er forse verschillen zijn in de voorkeuren voor denominatie, aanpak en bijzondere kenmerken. De vraag resteert of de diversiteit in het aanbod voldoende is om aan deze diverse vraag te voldoen. Deze vraag is in absolute termen moeilijk te beantwoorden. Het is niet mogelijk om iedereen een school die voor $100 \%$ aan hun wensen voldoet pal naast de deur te bieden.

Zoals in paragraaf 4 van dit rapport werd uiteengezet, maakt iedereen kosten om naar school te gaan. Deze kosten bestaan uit de feitelijk gereisde afstand, plus een eventueel verlies wanneer de meest geprefereerde school niet binnen bereik blijkt te zijn. Er is geen absolute antwoord op de vraag van hoe hoog deze kosten mogen zijn, maar in relatieve zin valt er wel wat over te zeggen. Voor de meeste mensen blijken de kosten, vertaald in afstand, niet bijzonder hoog te zijn, niet meer dan enkele honderden meters. Voor een substantiële minderheid lopen deze kosten echter behoorlijk op, tot boven de 10 kilometer voor $1 \%$ van de populatie. Dit bestaat - als alleen naar denominatie wordt gekeken - met name uit de feitelijk gereisde afstand, en voor slechts een klein deel uit verlies door het niet naar een school van de meest geprefereerde denominatie te kunnen gaan. Omdat uit de analyse volgt dat ouders ook waarde toekennen aan de andere kenmerken, zal het vaker voorkomen dat ouders verder moeten reizen en vaker voorkomen dat de school van hun voorkeur buiten hun bereik ligt. Hoe groter de behoefte aan diversiteit, hoe moeilijker het zal zijn dit aanbod in de nabijheid van mensen te realiseren.

Op basis van de leerlingenregisters kunnen deze kostencomponenten nader worden gespecificeerd. Er blijken grote regionale verschillen te zijn in het kwantitatieve aanbod van scholen, en ook in de plaatsing van deze scholen in relatie tot de woonlocatie van leerlingen. Hierdoor hebben leerlingen in verschillende regio's te maken met grote verschillen in de afstand die ze minimaal moeten afleggen om naar een school te kunnen gaan. Zulke verschillen zouden in de toekomst verder kunnen worden versterkt door de leerlingendaling. Hoewel we niet direct uit de data kunnen aflezen in welke mate dit aanbod in kwalitatieve zin aan de behoeften voldoet, kan uit de grote verschillen in afstanden die bovenop de minimumafstand afgelezen worden dat ook hier grote verschillen bestaan. Hoewel de meeste kinderen niet meer dan een kilometer verder reizen dan strikt nodig is, een klein deel van de leerlingen reist enkele tientallen kilometers bovenop de afstand naar de dichtstbijzijnde scholen. Dit zijn forse kosten. Er is uit de data niet direct op te maken wat de kosten zijn die gebonden zijn aan het genoegen moeten nemen met een school die niet aan de wensen voldoet, omdat de geprefereerde school te ver weg was. 
Uit de vignettenanalyse kon worden berekend in hoeverre met een toenemend aanbod aan scholen met een verschillende mix van kenmerken kan worden voldaan aan de voorkeuren van de populatie. Op basis van de uitkomsten van de vignetten kon de optimale school worden bepaald, als in iedere buurt slechts één school zou bestaan: de school die het beste aansluit bij de gemiddelde voorkeuren van alle ouders. Tevens kan voor iedere respondent zijn of haar eigen persoonlijk optimale school worden bepaald: de school met de door de respondent meest geprefereerde denominatie, aanpak en bijzonder kenmerk. Door de publieke en private optima met elkaar te vergelijken, kon worden opgemaakt dat in het gunstigste geval slechts weinig schoolkeizers tevreden te stellen zouden zijn met slechts één school in de buurt.

Door het aanbod uit te breiden met scholen met een gevarieerd mix van attributen, kan de tevredenheid het aanbod snel worden verhoogt tot een punt waar weinig mensen behoefte zou voelen om ver te reizen voor een betere optie. Wel blijft zelfs bij een aanbod van 20 of meer scholen met gevarieerde attributen een deel van de populatie over die tamelijk sterk ontevreden zou zijn met het aanbod. 